\title{
Rock: Symbol of Self in the Process of Individualization - Alchemy Transformation in Sandplay Therapy -
}

\author{
An Eun Sun
}

This study investigated the process leading to individuation by examining the symbolism of rocks that emerged from sandplay therapy for a middle-aged woman from the perspective of analytical psychology and alchemy. The rock symbolizes an unchangeable life force, nurturing, recovery, source of living water, grave, and place in contact with spiritual energy. The alchemical process of creating new substances using existing substances proceeds in the order of calcification, dissolution, solidification, sublimation, decay, separation, and unity. In this study, the client expressed her unconscious through the rocks in the sand tray, which corresponded to the calcification of alchemy. Afterwards, the client expressed feelings such as despair and sadness that existed deeply within her, which were linked to the process of dissolution and coagulation of alchemy. Finally, the client could proceed with the process of individuation through self-integration with her shadow by accepting the suppression and wounds of her heart that were suppressed for a long time in consciousness, which is connected with the process of sublimation, corruption, separation, and unity in alchemy. The process of individuation involves completing the true Self by integrating the Self that exists inside the individual. We can integrate these processes through a confrontational dialogue between consciousness and the unconscious through symbols.

Keywords : Self, rock, alchemy, individualization, analytical psychology

\footnotetext{
* Doctorate candidate of child counseling and psychotherapy, Department of Child Welfare Studies, Namseoul University(pre-woman71@hanmail.net)
} 
Journal of Symbols \& Sandplay Therapy, Vol.12 No.1.

\section{INTRODUCTION}

From a long time ago, human beings believed that spirits and souls dwell in certain rocks. Many of these rocks resemble human beings, such as menbirs from ancient times shaped like the human face, or the heads of Greek Gods. Such acts of breathing life into rocks and applying meaning to them may be considered a projection of the inner unconscious (Jung, 1964/2013). As such, human beings have an unconscious motive to identify with objects connected to the state of their inner ego.

From a very long time ago, human beings attached psychologically important symbolic meaning to the rock. The primitive people believed that unprocessed rocks in nature were the abode of spirits or gods, and they worshiped tombstones and hoarstones. For centuries, caves and rock walls with animal paintings were considered by many as religious sanctuaries (Jung, 1964/2013). If the paintings were discovered in other ordinary places, people might not have placed any significant meaning on them. Here, the symbolic aspects of the rock may have been what brought a sense of worship and reverence.

The rock contains various symbolisms: a place of nurturing, a place in contact with spiritual energy, recovery, source of the life water, irresistible force, expression of the human being, the grave, vitality and spirituality. It also symbolizes the foundation or nature of the Self, the oldest unconscious aspect of the human psyche (Ackroyd, 1993/1997). The symbolism of the rock indicates a need to be broken and tempered to extract what is divine and fundamental from within. The symbolism draws a parallel with the individuation process of personalities. Individuation is also something that cannot be achieved with one or two tries; it requires a set of processes.

Individuation is a process of overcoming personal limits and fears to develop and integrate the distinctiveness of the individual. In other words, it is a process of discovering one's authentic self. Furthermore, it is a process of integrating the consciousness and the unconscious utilizing direct dialogue between the two through symbolism (Jang, 2017). In that sense, individuation is a process of recognizing the opposing elements in the Self within conflict and attempting to integrate the Self through acceptance. 
The development process of the human psyche, which Jung referred to as individuation, can be symbolized with alchemy. The vessel required by the alchemist to extract pure gold resembles the womb of the Earth Mother. Within this vessel, circulation and transformation of matter occur, and in the process the alchemist makes an honest effort to reveal the secret of chemical transformation (Jang, 2017; Fideler, 2014).

In essence, alchemy attempts to transform a block of impure metal into pure gold or silver. In that sense, alchemy symbolizes a spiritual journey from ignorance to enlightenment (Miranda et al., 2008/2010). The alchemist seeks to take existing material and turn it into new form, in particular ultimate matter such as gold. Throughout the process, the alchemist repeatedly experiments with the numerous methods manifested within himself until he gets the desired outcome. It is an aim to find the philosopher's stone, which indicates a psychic value in alchemy (Shin, 2013). Furthermore, it is in parallel with the individuation process in which the firm personal limits and boundaries are broken and overcome to initiate development toward a new Self.

In the sense that the process of alchemical transformation involves the projection of the alchemical psyche on matter, it bears comparison with in-depth psychotherapy, which projects the psyche through symbolism. In this process, the therapist's consistently acceptive and supportive attitude becomes a crucial element for the client's transformation. Set on a safe foundation provided by the therapist, the client brings new things that were unknown or opposing elements of the unconscious into a union (von Frantz, 1981). Throughout the process of sandplay therapy, the client becomes an alchemist under the safe protection of the therapist, projects his or her issues on the rock and uncovers a truly desired hope.

The rock that appears in sandplay therapy has various symbolic meanings. It may indicate permanence, stability and reliability, but also stiffness, coldness and firmness (Cooper, 1978/1994). At times the symbolisms express the current psychological state of the client working on the sand tray, and at other times they reveal hopes for the future as a solution to break away from present circumstances. In particular, the rock in sandpictures holds the meaning of change and transformation. The client takes the issues or circumstances stuck firmly within his or her inner world and projects them on the rock, hoping that they will break and 
Journal of Symbols \& Sandplay Therapy, Vol.12 No.1.

transform into a new, desired form at the end.

This study seeks to explain the symbolism of the Self that appears in the individuation process by looking into the characteristics and symbolism of the rock, and draw a comparison with the alchemical transformation process to offer a more precise explanation of the development process of the Self, or the individuation process.

\section{ATTRIBUTES AND SYMBOLISMS OF THE ROCK}

\section{A. Attributes of the Rock}

The rock is a solid body of natural minerals. It is the most solid and durable material in its natural existence and has properties that cannot be seen in other natural materials, such as soil or wood, in terms of weight and compressive strength. Rocks vary in composition, organization, and characteristics depending on the process of formation, substances, and environmental circumstances such as diastrophism. Rocks can be largely divided into igneous, sedimentary, and metamorphic (Chong, 2014).

Igneous rock is produced when magma cools; the bright color area is the trace of the flowing lava. Sedimentary rock is formed when mineral particles, or sediment, carried by water and wind are deposited in low pressure and low temperature. This sediment is often formed by weathering and erosion and moved to lower places by gravity. Once hardened, it becomes a sedimentary rock. Metamorphic rock is created by heat, temperature and chemical activator or liquid. When subjected to high heat and high pressure, the rocks take on a new chemical composition or structure. During metamorphism, rocks are not in a liquid state but solid (Choi, 2013). Formed by volcanic activities, weathering, erosion, high pression and heat, rocks naturally harden and take on various appearances over time.

Rocks are conceived over hundreds of millions of years through the effect of soil, wind and even volcanic action, which are some of the most fundamental elements of nature since the beginning of time. The process makes us feel deeply the mystery and awe of nature. However, even rocks go through the process of decomposition. Despite how hard they may be, rocks are 
broken into stone pieces by rain or wind, which further breaks down into sand grains and eventually returns to its source: the soil. In the East where people tend to give meanings to natural phenomena and objects, the formation and decomposition of rocks was considered to represent the cycle of life and history (Chong, 2014). Rocks contain the circulation principle of being born in nature and returning to nature.

\section{B. Symbolism of the Rock}

\section{The rock as the mother symbol}

Rocks, along with mountains, trees and forests, form nature that makes us feel the totality of the cosmos. So sometimes rocks are described as the placenta of the eternal mother, meaning that the rock allow us to feel the virginity of the earth (Robert, 1989/2006).

Jung called the rock, a representation of the mother archetype which is the symbol of creation and birth, a pregnant mother symbolizing the unconscious (Jung, 1964/13). Sometimes rocks appear in the form of caves, which symbolize the womb that contains the meaning of a shelter. The womb is linked to birth and resurrection, and is connected to the center of the

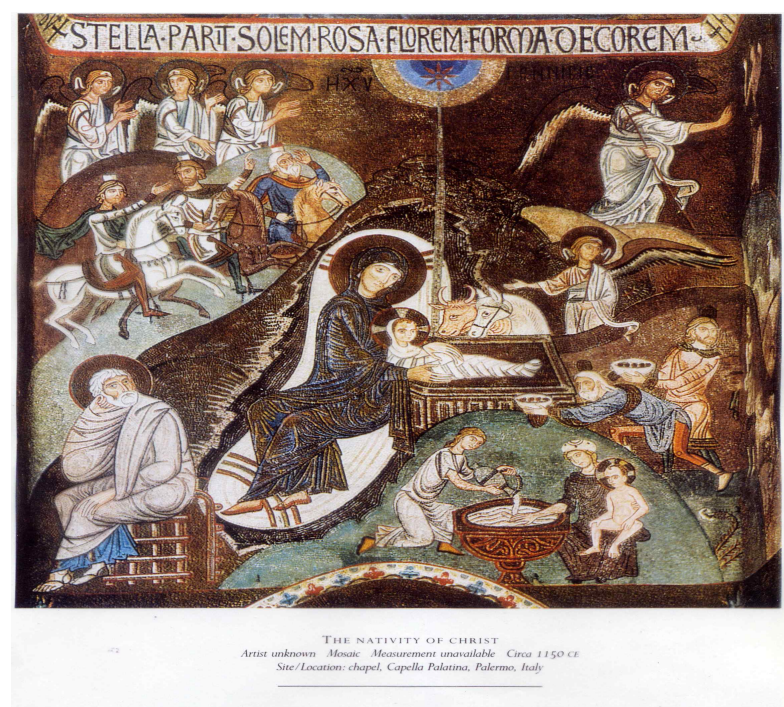

Figure 1. Nativity Scene

https://www.google.co.kr/search?q= nativity +scene\&tbm=isch\&tbo 
Journal of Symbols \& Sandplay Therapy, Vol.12 No.1.

cosmos. Seeing the cave as a mother symbol of life was attempted by many early psychoanalysts, who associated it the experience of the fetus swimming in the amniotic fluid, the birth canal and the birth trauma. This is because the darkness and the coziness of the cave well describes the mystery and the benevolence of the mother (Han, 2007, requoting). Analytically, going into a cave can be described as a kind of regression, a desire to return to the mother's womb, or the source of life.

The portrait of the Virgin Mary holding the Son (Figure 1) is directly related to sacredness. In the image, there are a cave, a stone pillar, and a rock around Mary. The rock of the temple in Jerusalem is a symbol of the Great Mother (Neumann, 1974).

\section{The rock as the symbol of transformation}

The element is the fundamental constituent of matter, and the mineral is the elements joined by chemical bonds. Rocks contain these minerals. Usually, jewels are cut or polished to accentuate the beauty. Jewels in their pre-polished state are called gemstones. The diamond, one of the most valuable and prized jewels in the world, is not so beautiful when in its gemstone state. To produce one carat of diamonds, an average of 250 tons of earth have to be excavated through different, complex processes. Around 40 to 50 million carats of diamond gemstones are mined each year, but only a small amount is qualified to become jewels. After being polished by artisans, diamond gemstones are born as the most popular jewel. Diamonds have long been loved for their outstanding beauty and are widely used in many tools and machinery for their toughness (http://www.naturehistory.org/2016/09/blog-post.html). Beroalde de Verville describes the transformation of gemstones, which are masses of impurities, into a beautiful jewel in his literature Steganographic Collection (Jung, 1985 requoting):

If anyone sometimes wants to transform a small amount of frankincense, compress it to extract the frankincense mucus as transparent tears, have him pay attention. He will observe, at a fixed time, something like a substance discharged from the philosophical matter under the pressure of mild fire. Because, as soon as his black purple stimulates for the second time, there will be something like a drop of water, or a flower, pearl, or jewel. Flowing in very transparent white light, it will become varied. Then, it will be decorated with the spirit of philosophers, beautiful red jade (ruby) which 
is the true fire of light, and the glory of the celestial stone.

Gemstones in rocks are simply stones of no value. But through the lapidary work by artisans, they are transformed into beautiful and valuable jewels such as diamonds, rubies and pearls.

\section{The rock as a symbol of sturdiness and determination}

The toughness of the rock is not something that has been made overnight or over a short period of time, but a consummation of many years. During this time, the rock endures the rain and the wind and other natural phenomena. The solidness attained from years of endurance brings a feeling of firmness and permanence.

In his poem, Chi-Hwan Yu depicted the invariability of the rock in its containment of life, its endurance and pain, and the determination that surpasses the pain (Yoo, 2002).

\section{Rock}

\section{Chi-Hwan $Y u$}

When I die, I shall be a rock.

Not to be tainted by pity,

Not to be moved by joy and anger.

As the rain and wind erodes,

I will whip myself inwards

In eternal, stone-hard silence.

At last, I will lose memory of life,

Drifting clouds, distant thunder,

Sing I will not, even in dreams.

I shall be a silent rock

Though I may be broken in two.

From "The Chapter of Life"

In Yu's poem, the rock symbolizes a tenacity that does not sway to emotions. It does not waver to affection or anguish that arises in the affairs of men, and does not budge to things 
Journal of Symbols \& Sandplay Therapy, Vol.12 No.1.

such as joy or anger. Even under rain and wind, the rock remains unyielding and quietly withstands it all, keeping its firmness. Yu takes this trait of the rock and personifies it, singing, "I will whip myself inwards." By doing so, the rock at last transcends and overcomes all fluctuations. In addition, the rock holds an extreme form of patience that allows it to overcome pain and adversity. It is portrayed as firm determination itself, not making a sound even when broken in two. It is a representation of the human determination to push forward with a firm will in all circumstances (Kim, 2003).

When people run across rocks that resemble the looks of human beings, they place and project awe and life on them and make connections to perpetuities in the psychic world such as eternal love or friendship (Jung, 1964/ 2013). That is why there are novels on rocks and certain rocks are held in awe or worshipped in hopes that wishes will be granted.

\section{ALCHEMICAL STAGES IN THE TRANSFORMATION OF MATTER}

\section{A. Transformation of the Rock in Sandpictures}

According to Jung, the characteristics of alchemy are similar to the process of drawing out the inner nature on the path of finding the nature of the soul, which is a process of discovering one's most noble and natural values hidden inside the unconscious, as opposed to leaving them to remain in the depths of the unconscious (Lee, 2016, requoting).

Alchemical change is a process of dialogue with the inner matter and projecting the human psyche on it (Yoo, 2016). In an alchemical process, the matter must first be broken to be transformed, then new elements must be added or mixed. It also requires a large and sturdy vessel that can hold the elements as they are broken and mixed. Similarly, in the psychological transformation of the psyche, the original structure is thoroughly analyzed before new attitudes, new experiences and new prospects are added to it (Jang, 2017). In that aspect, the alchemical and psychological transformation processes are similar to each other in their fundamental meaning and procedures.

Edinger (1984/2016) described the process of alchemical transformation in seven steps: 
calcination, dissolution, coagulation, sublimation, putrefaction, separation, and conjunction. He believed that the client in sandplay therapy also goes through similar steps in the transformation process of integration in becoming a wholesome human being. Generally, the matter in alchemy suffers and dies, and is then reborn in the form of a new existence. In other words, the function of suffering as a rite of passage is projected on the matter, and through alchemical steps that correspond to pain, death and regeneration, the matter turns into jewel (Mircea, 1976). By drawing parallel to this alchemical process, this study seeks to examine the case of a middle-aged female client and the rock that appeared in her sandpicture that symbolizes the Self, from the perspective of analytical psychology and alchemical transformation.

The client, a middle-aged woman in her forties, had been struggling with an identity crisis within her family after marriage due to unresolved attachment issues from childhood and had difficulties in interpersonal relationships. She took sandplay therapy that consisted of twelve sessions. As the sessions progressed, her complaints emerged in a spiral form, going back and forth repeatedly between exposure and resolution.

\section{Calcination (Passion and thirst for the fire of love)}

In alchemy, calcination (calcinatio, burning) is the drying or burning of a material due to the exposure to intense heat so as to transform into a new form. In sandplay, this stage can appear as burning fire, heat or dust. Psychologically, it would be related to the drying up or burning of the ego's existing interests as well as feelings of depression or emptiness. It could also indicate passion being repressed or frustrated, or conflict between aspiration and ego being intensified or heated (Jang, 2017).

Neumann associated this stage of sandplay therapy with symbols related to darkness, blackness, death, conflict, fear. They are the symbols of the undifferentiated Great Mother, and the ego germ that is yet differentiated from the Self (Shin, 2013 requoting).

The client spoke about her inner frustrations and the ego:

"I don't want to look at this rock because it gives me a feeling of frustration and suffocation. It reminds me of when I was young and a snake popped out from the crevice of a rock. When I passed by two big rocks on a trail, the candy in my mouth got stuck 
Journal of Symbols \& Sandplay Therapy, Vol.12 No.1.

in my throat and I almost died. I was so focused on the big rock and it got e wrought-up that I couldn't see anything else in the tray."

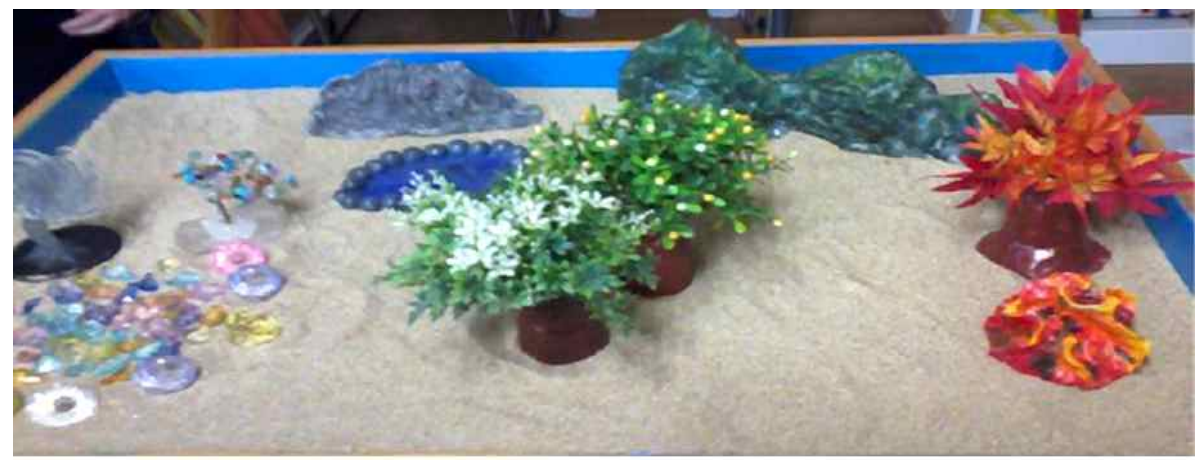

Figure 2a. First picture of sandplay

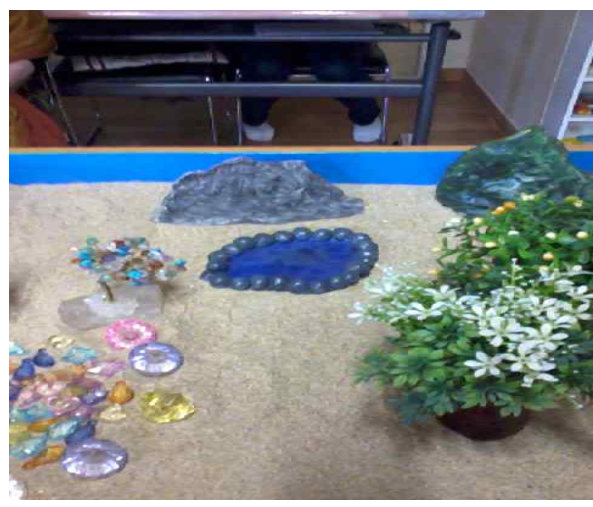

Figure 2b. Unpleasant rock

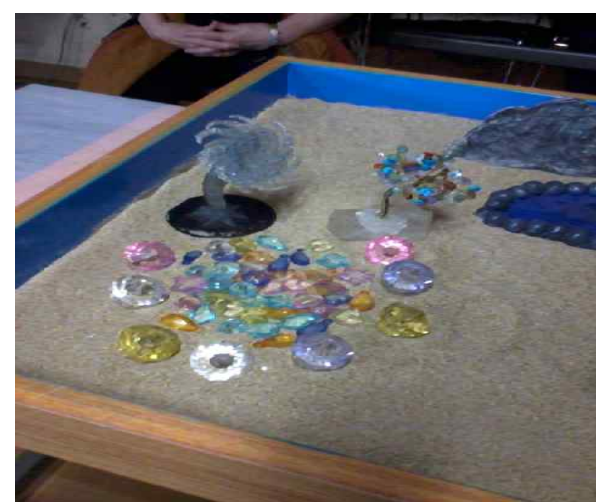

Figure 2c. Jewels in the Unconscious

Rocks in sandplay generally symbolize stiffness, coldness, and hardness (Cooper, 1978/1994).

The client's rock expresses frustrations due to unresolved inner problems and the ego's desire to progress further and the contrasting reality. It is an emotional expression of the dissonance between the client's desire for change and the reality.

The volcano, which is associated with heat and fire, placed next to the rock symbolizes the undifferentiated state of chaos and the feelings of anger and also shows the regressive death of the ego. Psychologically, in sandplay, the client's ego is in a state of stagnation, playing a less important role and instead depending on the unconscious. The fire also expressed a chaotic 
psychological state that the client is unaware of, relating to regression, depression, anxiety, anger, fury, regret, guilt, and negative feelings. In sandplay, fire can symbolically represents not only anger but also consciousness (An, 2014). From another psychological viewpoint, symbolisms of fire are described as the heat of passion and the light of consciousness (Cooper, 1978/1994).

The rock and fire figures in this sandpicture show that there are frustration, confusion, anxiety, anger, and fury as well as passion and the light of consciousness in the client's inner world.

\section{Dissolution (The pain and cry in pursuit of oneself)}

Dissolution (solutio, dissolving) in alchemy refers the turning of a solid material into a liquid or into particles. Symbols of dissolution found in sandplay are water, flood, rain, etc. Psychologically, dissolution represents the ego's losing its self-defense capability. For the ego to form a broader and more comprehensive perspective, the energy oriented outside ought to be directed to the unconscious, which would provide the energy necessary to form a new system of ego.

In this stage, the old ego patterns, i.e., old circumstances and elements, are eliminated. Old attitudes are washed away and purified, leaving only the valuable attitudes and actions. In sandplay, this stage would be represented through washing, wiping, taking a bath, or peeing; figures that express anguish and grief would be used; symbolisms related to easing of hardened emotions and crying would appear (Jang, 2017).

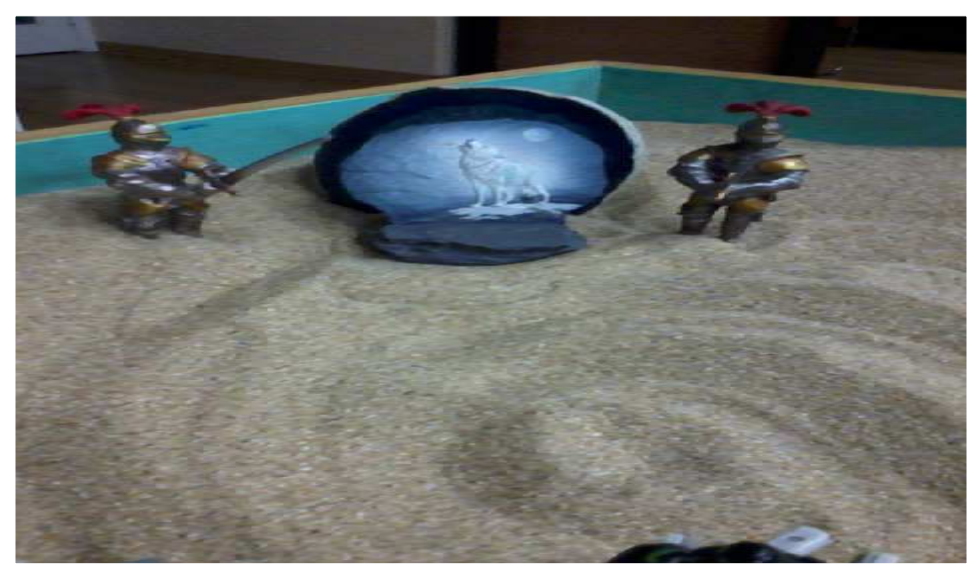

Figure 3. Rock with Wolf Howling and Two Guards 
Journal of Symbols \& Sandplay Therapy, Vol.12 No.1.

The client made the following comment about her inner frustrations and the ego:

"It appears that this wolf is crying out to God for the sorrows and injustice it experienced. I experienced unfairness in life because I was not born a son. I think [the wolf s cry] is a struggle to protect things that are precious to it."

The client's comment seems to be a projection of her unresolved feelings into the crying wolf. The projection would break the psychological wall she has built in life. In other words, the client is experiencing her existing, unstable ego being disrupted and broken for the birth of a new ego.

As seen in figure 3, the wolf figure is attached to a circular agate as a background, which is intended to be a cave. Two soldiers are standing on both sides of the cave to guard it. It feels as if a being, which is projected as a wolf, is protecting what is inside the cave by standing in front of it and, at the same time, is informing $\operatorname{god}(\mathrm{s})$ about the being in the cave and the surrounding situations.

Caves in sandplay represent a place for hiding or refuge and symbolizes the uterus. Although seemingly empty, the cave is connected to birth and resurrection, leading to the center of the cosmos. Caves are sometimes associated with the underworld and also the gate to hell, mainly connected to deep human unconsciousness (Miranda et al., 2008/2010). Moreover, the cave is also a symbol of the feminine, the world heart, the unconscious, gate to the underworld, initiation, and wisdom (David, 1993). The symbol of the cave in this sandpicture is the shadow of the feminine that experienced unfairness or injustice for not being born a son.

The wolf carved on the rock has dual symbolisms. In Christianity, the wolf represents the brutality of devouring sheep. But the Romans regarded the wolf as symbolizing the mother instinct of the she-wolf that raised Romulus and Remus, the twin brothers who founded the city of Rome (David, 1993). Also, the wolf represents desires, and desire is fire. So, desire eats itself and burns. After descending to a place reminiscent of hell, the ego is born again as a pure being like a phoenix. suggests that the wholeness of the Self emerges in the very place where the needs of the ego met frustration (Edinger, 1984/2016).

In alchemy, dissolution involves burning or melting impurities around the gold. So, the client's sadness and feelings of unfairness, symbolized by the wolf in the sandpicture, must be 
revealed and burned to show the nature of a purified Self.

In this stage we can see the client's desire for the growth of a new ego (as the existing ego is repressed) by disclosing her problems.

\section{Coagulation (Rebirth of the Self)}

Coagulation (coagulatio, hardening) refers to matter turning into a solid substance. Things that were not in the conscious before take on a new form in a material sense. In sandplay, it can be shown through the images of the earth, dust, mud, soil, rock, stone, and so on (Jang, 2017).

The client expressed how she wants herself to become through the mixture of sand and water.

"This is a face of a smiling person. The large rock face is the face that I want. My facial expression always appears stiff, and people ask me whether I am angry."

The client used water to express what she wishes of her. Water is formless; can be transformed into solid, liquid and gas; and is the source of all life. Water, which purifies and heals, is also a symbol of rebirth (Park, 2012).

In general, the use of water in the sandplay therapy process indicates the ego intention to

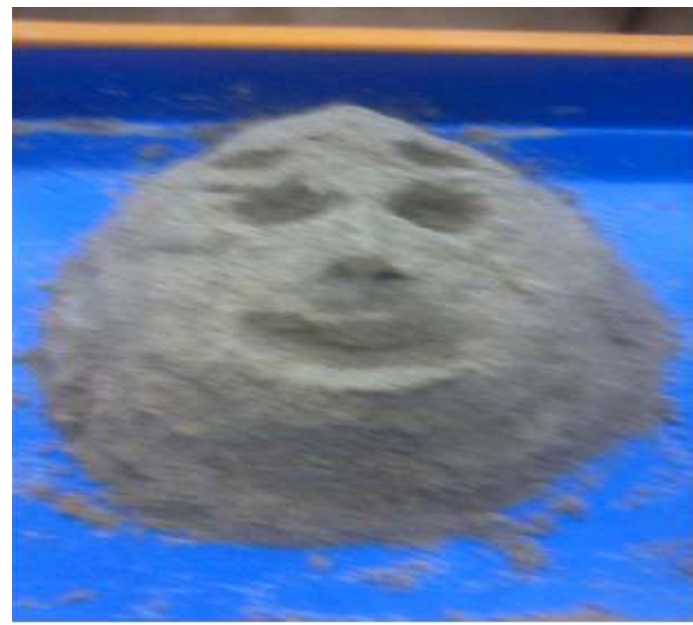

Figure 4. A large rock face 
Journal of Symbols \& Sandplay Therapy, Vol.12 No.1.

directly and closely take part in the unconscious. In other words, access to water involves the trust required to access the unconscious, and liquidity guides the ego to the Self to bring new energy (Turner, 2005/2009). The large rock face created by the client by mixing sand and water can be seen as a symbol of psychological healing and rebirth. It is a symbol of something that is perfect and ideal imagined by the client (Hawthorn, 1988). For the client, the large rock face is a symbol of the psyche that guides her in the journey of discovering a genuine Self.

In alchemy, coagulation fully manifests the alchemist's inner world and is a transformation process involving hardship. In sand tray, coagulation contains the theme of a symbolic manifestation of client's inner desire, just as liquid becomes solid, hard as lead, and just as food becomes absorbed in the body and become part of it (Edinger, 1991). In a deeper aspect, coagulation is like the moment of collecting one's breath for the changes for a new situation or pausing to shoot an arrow at a target (Shin, 2013).

At this stage, the client is expressing her true desire on a large rock face in the sand tray, and on the face of a large rock in a sand box, which also represents a moment of pausing for rebirth. This also reveals the desire for individuation within the client.

\section{Sublimation (A leap for the new)}

Sublimation (sublimatio, uplifting/inflating) is the process in which matter transforms into vapor through distillation. In sandplay, that would be represented through flying, ascendance, stairs, ladder, airplane, bird, wind, breathing, etc.

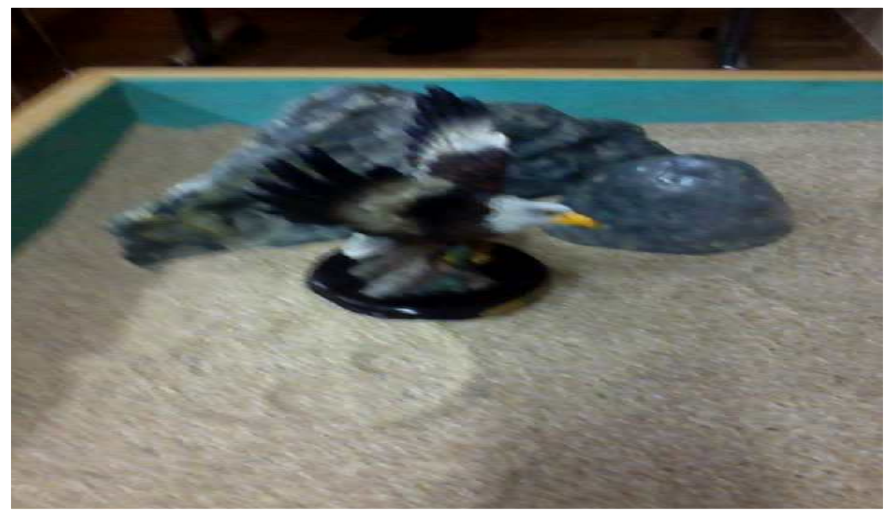

Figure 5. An eagle in front of a rock 
The psychological meaning of sublimation is that the ego would surmount the limitations of the material reality to gain a broader perspective (meaning) or to pursue new possibilities. In a negative sense, exaggerated sublimation would mean dissociation from the reality (Jang, 2017).

The client expressed her desire for a new ego through a flying eagle.

"The eagle in front of the rock is going to fly for a new life."

In order for a raw gemstone to become a valuable jewel, it needs to be broken and polished. Likewise, for the eagle in front of the rock to fly freely in the sky, it must first obtain a new beak that is tough and sharp. To this end, the eagle knocks its beak against a rock until it plucks it out. And with the new beak, the eagle plucks out its old-aged feathers to grow new feathers. The eagle must endure a painful process of rebirth to be able to fly, and the client is expressing her desire for transformation and rebirth (for growth) through an eagle. Now, with the strong inner desire for a new life, the client would have to face the pain of discarding old attitudes, premature ways of expressing emotions and narrow views that have inhibited her from flying.

In alchemy, sublimation is a chemical process in which heat is applied to a solid, immediately turning it into a gas that would then rise to the top of the alchemical vessel. And up there in the colder layer, the gas becomes a solid again. Sublimation is the desire for ascendance, and it associated with something of a lower form transforming into a higher form (Edinger, 1984/2016).

In alchemy, as a chemical sublimation process, the heated solid immediately becomes a gas and rises to the top of the alchemy container and becomes a solid again at the top, a cold layer. In other words, sublimation is a desire to rise and is related to the conversion of lower forms into higher forms (Edinger, 1984/2016).

The power of a flying eagle comes from its wings. The higher it ascends, the further it sees. This metaphor is related to the ego, which is narrow-sighted, pursuing a broader world, a life of a higher dimension. By placing an eagle in front of a rock, the client symbolically expressed how her ego, which experiences frustrations from issues in reality, is in the pursuit of 
Journal of Symbols \& Sandplay Therapy, Vol.12 No.1.

a life at a higher level (Robert, 1989/2006).

At this point, the client is expressing her hopes to overcome the reality and achieve ego growth through the strength of the eagle, wings that flap freely, and eyes that can see far From this we can see that the client wishes to further develop her individuation process through ego growth.

\section{Putrefaction (Forgoing the past for the new)}

Putrefaction (mortification, killing/dying) in alchemy stand for death or annihilation of a substance. It can be expressed as dead bodies, graves, coffins, shooting, stabbing, killing, burying, and excrement such as feces in sandplay therapy. The psychological meaning of such emotional state is that the ego or the ego complex is killed so as to be transformed by the Self. On the negative side, it may also symbolize repression or inhibition (Jang, 2017).

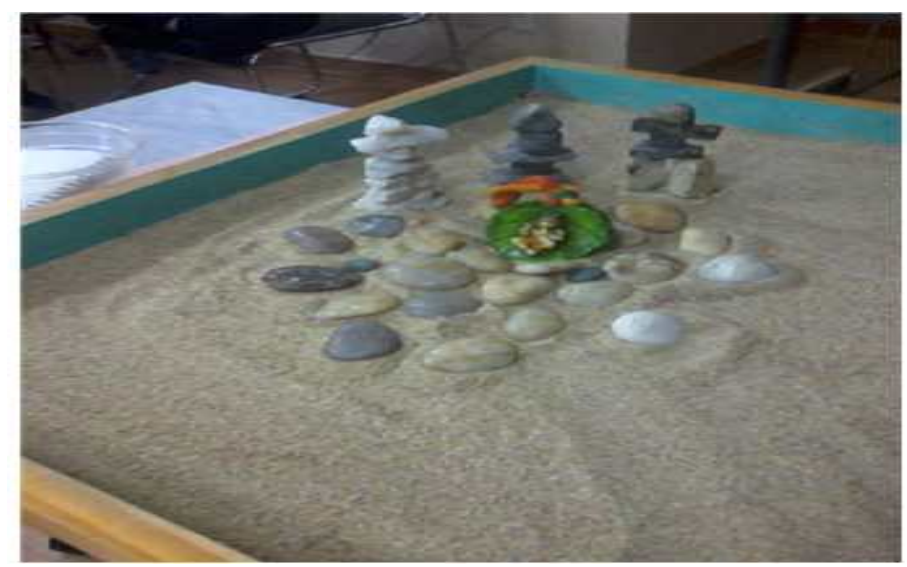

Figure 6. Krishna on a rock backed by cut stone towers

The client used dolmens to represent what needs to die and become annihilated in his inner world for the creation of a new ego.

"At the back are dolmens. What needs to die of me are negative thoughts about me and others, frustrations and criticism." 
The god Vishnu, which is placed on a rock in the client's sand tray, symbolizes man as macro-cosmos. Krishna, the most beloved incarnation of Vishnu and the most human, symbolizes the world which is represented by a disk, a conch, a lotus flower or a club that he holds in his hand (David, 1993). The appearance of a god expresses that the client's becoming anew is linked to god's help and grace.

Dolmens represent death. Death is to do with putrefaction, and also suffering from grief and sadness. What needs to die in the client are various negative aspects that exists at the back of her consciousness as shadows. They are like discarded grain or tools in a dark warehouse; when left abandoned for a long time, it will mold or rust. In other words, they are psychological attributes left undifferentiated because they lost the opportunity to become conscious.

Human life goes through a cycle like grains. Grains contain life, die, and return to the womb of the Great Earth Mother with the hope of sharing the fate of the seeds that had been sown. However, the death of grains is an annihilation but is for a new birth; they are strong and un-destroyable like a rock (Robert, 1989/2006).

In alchemy, the birth of a new substance involves breaking the order of the existing substance into pieces. Through dolmens, the client was able to find the wish for a new life through the death of her negative personalities, not leaving them abandoned in a warehouse. It is related to the achievement of individuation, which involves accepting the shadows and turning them into the energy for growth.

At this stage, it could be seen that the client has a desire to resolve inner elements that hindered her ego growth and individuation in order to take her individuation process to a higher level.

\section{Separation (Discovery of a new "I")}

Separation (separation, separating) is a process similar to dissolution, but more definite, in which a mixture of disorderly or lower-level substances is separated to create a mixture of purer substances. In sandplay therapy, this would be associated with images of a knife, cutting, tearing, classifying, folding, arranging, choosing between the two, leaving, distancing, dividing, 
Journal of Symbols \& Sandplay Therapy, Vol.12 No.1.

and divorcing. Psychologically, it would represent the process of ego separation from the state of being in an excessive identification with parents, people, group values, complexes, etc. (Jang, 2017).

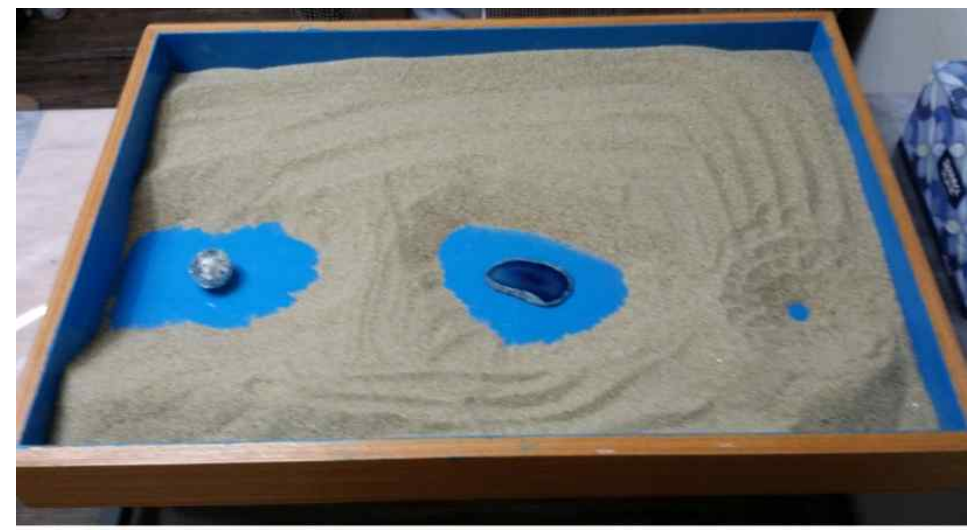

Figure 7. Separating

The client placed a jewel on a torn piece of paper for the growth of a new ego and said:

"I was attracted to the agate rock in the middle, so I brought it. I was attracted to the ball on the left because it shines. I think deep down in my heart, there is something like this jewel."

There was an ancient belief that carrying an agate would make one appear invisible. The agate symbolizes courage, longevity, and prosperity. In the past, the stone was hung on the bull's horn to wish for a fruitful harvest period.

The client divided the tray into separate spaces, exposing the blue bottom. Through its symbolism, the client is representing her journey to find a new Self, separated from her old ego.

In sandplay, the process of separation is closely related to the symbolism of death as separation can be experienced as death. An example would be to extract the spirit from the rock or the soul from the body. Then the old body, which is the manifestation of the elements of the psyche, would die (Edinger, 1984/2016).

The client placed a silver egg on the left side of the tray, which, in alchemy, represents the chaos captured by the alchemist. In other words, it is the prima materia that binds the 
world soul inside. From the egg, which was symbolized by a round caldron, rises a psychic that is now free, like the eagle or phoenix. It would eventually be re-identified with Anthropos, which was trapped in the body (Jung, 1985b).

The client's hand mark on the right side of the tray is like the pilgrimage trails in Nepal, or the trail of enlightenment. It is a representation of her future journey of creativity and growth in which her ego becomes separated from the ambiguous ego of the past. At this stage, it is clear that the client's desire for individuation is become stronger and that her inner ego is becoming more elaborative.

7. Conjunction (Constellation of the jewel, or the Self; discovery of an integrated Self)

Conjunction (joining or uniting) is the union of two previously separate substances to create new substances in alchemy. In sandplay, this stage can be symbolized by physical contact or figures that come together symbolically or transform into something different, and so on.

Unity forms harmony, connects, and unites the opposites. It is related to obtaining the philosopher's stone and gold through the highest level of achievement. Precious stones like jewels and gold, mandala, sacred items-through them a harmonious insight that resolves both internal and external conflicts are represented (Jang, 2017).

An adequate amount of water was used in this sandpicture. Water as a symbol of rebirth is expressed as the life water, well, drinking water, river, sea, and baptism. With the intentional behavior on the part of the ego to go towards the unknown, the nurtured ego would become integrated into the domain of the Self and move towards a single direction (Turner, 2005/200 9).

The amethyst symbolizes the stage of unity in which the cosmic materials are born as one. The individual elements of the client's ego would be integrated to express her uniqueness. The psychological feature of this stage is the integration and resolution of the opposites inherent in the personality. The formation of a harmonious relationship between the ego and the Self would raises warm feelings. The client would become aware of her desires inside her deep inner world, gain an insight as to who she truly is through the energies of those desires, and adapt to her daily life as a new "I." 


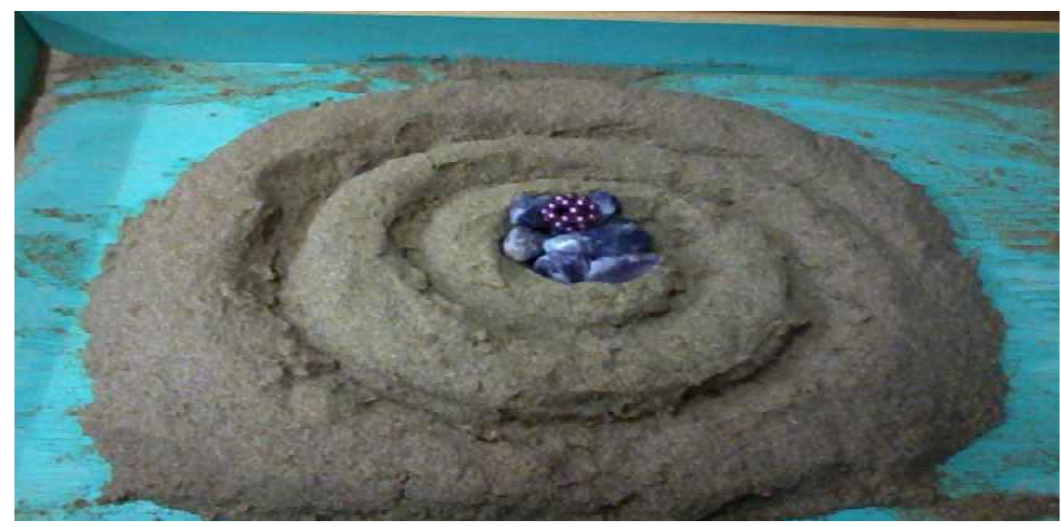

Figure 8. Amethyst Jewel and The emergence of creation and birth Self

The client represented her awareness of the new Self, its energy, and the growth of a new "I" with jewels and pearls.

"I let my hands do the work, and I brought purple jewel and pearls because my hands reached out to them. I felt energy as I mixed water and sand to form a shape."

This sandpicture shows that healing is taking place. Jewels or precious stones emit radiance based on their unique colors. For centuries, jewels were used to represent one's status. Certain jewels were believed to have the power of healing and protection. Red jewels represent passion and vitality, and some jewels gemstones are associated with a person's birth; each jewel has a different implication (Miranda et al., 2008/2010).

In alchemy, the image in the alchemist is finally materialized through various stages of refinement. Union in sand tray represents a resolution to the conflict between the opposites inherent in one's life or personality, and the formation of a harmonious relationship between one's ego and the Self. In other words, internal or external conflicts that were in a confrontation are now integrated and in a harmonious state (Shin, 2013).

Red is the color of warmth which vitalizes the jewel, and blue is the color of psychic coldness. The color purple is a combination of these two colors. Hence purple symbolizes the union of these two polar opposites on a spectrum. The combination of the warm red and the cold blue is associated with wholeness and totality, which refers to a mixture or union of 
confrontations that varies depending on the level of consciousness. And while the color purple represents two polarities on a spectrum, i.e., red and blue, it could also represent an unhealthy mixture of the same antipodes at the same time (Theodor, 2010). Jewels or precious stones emit radiance based on their unique colors. Jewels come from the ground and hence they are symbols of purity and of spiritual energy representing divine authority (Miranda et al., 2008/2010).

Jung said that the meaning of a person's life is in that person. This means that we have the key to life inside of us. However, that key cannot be found right away because they are in the unconscious. The key is the Self, which is a human nature and an individual's unique psyche that is innate (Rhi, 2004 requoting).

The spiral in client's sandpicture is an ancient symbol of energy and the rhythm of life. In ancient times, people believed that energy flows in the form of a vortex. The vortex is closely related to the spiral in its form and symbolism, and they are often confused. Most importantly, these forms are associated with powerful forces such as the revolution of the earth and the whirlwind. In most cultures, the vortex is considered feminine (Miranda et al., 2008/2010).

In images related to the mandala symbol, the spiral often represents the theme of the rotating movement towards the center. More precisely, the spiral is a path towards the center and also from the center. In this respect, the symbolism of vortex was often mentioned together with the symbolism of the maze. Wamoon, or the traditional spiral motif pattern in Korea, represents death and rebirth, generation and regression, going backward and forward, and the eternal repetition of the primal rhythm of life (Rhi, 2004). The spiral pattern in the client's sandpicture and the jewels on top represent the both the sun and the moon and also the masculine energy and the feminine energy (David, 1993), suggesting that the client is moving toward the union of the opposites through healing in sandplay therapy.

\section{CONCLUSION}

This study analyzed, from the viewpoint of analytical psychology and alchemy, the process of individuation of finding the genuine Self through the nature and symbolism of rocks that appeared in the sandplay process of a middle-aged woman. A material goes through seven stages 
Journal of Symbols \& Sandplay Therapy, Vol.12 No.1.

of alchemical transformation: calcination, dissolution, coagulation, sublimation, putrefaction, separation, and conjunction. The client showed her journey of finding the Self through the individuation process through the rocks and circumstantial changes in her sandplay therapy process.

Through her sandplay process, the client was able to identify the source of her frustrations and confusions, achieved integration by discovering and accepting the shadows in her deep unconscious, and reexamined the meaning of her life.

The color purple of the amethyst in the last sand tray is a combination of red, the color of warmth that brings something to light, and blue, the color of psychic coldness, and hence symbolizes the union of the two polarities on a spectrum. The symbolism of purple signifies that the client's feeling of anger and of coldness have been integrated through the sandplay process. The union also implies that the client has developed the energy to begin a new journey for individuation and ego integration. This is in sync with the study of Kim (2010) on art therapy, which found that psychological changes of an individual and resolutions of inner problems are linked to colors. In other words, changes in the colors of sandplay figures are related to inner healing and ego growth. Judith Harris used the light spectrum to showcase the relationship between instinct and archetype, and explained that the infrared pole of the spectrum is closer to the instinct, i.e., physiological and instinctive awareness, and the ultraviolet pole of the spectrum is closer to the archetype, i.e., psychological, spiritual, dreams, images (Harris, 2001).

Just as alchemy begins by putting a material inside the vessel, transformation in sandplay therapy begins by the client's putting his or her hands in the sand tray. The feelings in this middle-aged client's deep inner world that were chaotic and difficult to accept surfaced to the conscious through the rocks in her sandpictures. It was through these visualized and objectified rocks that the client was able to begin the process of individuation. Just as the rock must go through the process of transformation inside the alchemical vessel, the client was aware that her inner world ought to accept and endure the process of the Self, through individuation, transforming into more mature and integrated being (Weinrib, 2004).

Individuation is an innate task for any human being that allows the development and unfolding of one's unrealized potentials in life. In other words, the genuine Self would come to 
understands the inner voice of the unconscious and achieve growth in one's own unique way. The development of a mature personality involves the separation from and reinforcement of the ego, the ego and the Self forming an axis, and the discovery of one's genuine Self.

The experience of individuation can be attained when achieving the union of the opposites through psychic conflict or expressing and accepting repressed emotions and consciousness. Through its representation of symbols, it can bring changes in attitudes (Lee, 2005). Individuation is also a lifelong process, and changes are brought to the personality through the unique and special self-experience of each individual (Jung, 2004a).

Sandplay therapy is psychotherapy that enables clients to express their emotions, confront their shadows and achieve self-awareness, which can effectively help the individuation process of adults. This is because it is possible to freely express emotions and thoughts according to changes experienced by the Self in an inner space that is expressed outwardly, i.e., the sand tray.

The problem of the shadow in relation to the Self expressed in sandpictures by clients does not have a linear form with a single direction but rather a spiral structure that contains the occurrence, resolution, and recurrence of the problem. In case where the client's expressions on the sand becomes deeper like the spiral, it appears that the same theme is being repeated. But every time it is repeated, the client overcomes sufferings and pain or endures that process and hence goes deeper into the core problem, goes through the process of integration, and experiences the domain of the consciousness being expanded (Jang, 2017). The spiral eventually leads to the center of the problem, through which the client confronts the essential problem in the inner world, finds resolution, and achieves individuation.

Throughout her sandplay process, the client was able to see her inner world that remained like a rock that has remained intact in nature, having never been abraded with a chisel. In other words, the client gained an awareness of herself having difficulties in relationships as she could not control her anger and feeling of unfairness associated with the fact that she was not born as a son.

Moreover, the client experienced an alchemical process which were manifested through the following themes: passion and thirst for the fire of love, pain and cry in pursuit of oneself, 
Journal of Symbols \& Sandplay Therapy, Vol.12 No.1.

rebirth of the Self, a leap for the new, forgoing the past for the new, discovery of a new "I," and constellation of the jewel or the Self, i.e., discovery of an integrated Self. Just as rocks have to be constantly polished to become a precious stone and go through the alchemical process to become gold, the client realized that she has to endure pain to the Self in her inner world. For the client, the rocks in her sandpictures are a symbol that helped her begin a journey of realizing a new meaning of life and meeting her genuine Self, thereby finding balance in life without being skewed to once side.

The policy implications of this study are as follows: First, this study explored rocks, symbols that often appear in sandplay therapy, to examine a client's individuation process which could be referred to by other therapists in understand and interpreting the individuation process of their own clients in sandplay. Second, this study can serve as data to help understand the stages of growth in the process of individuation expressed through sandplay figures for children and adolescents, who are at an important juncture in the individuation process, as well as adults who experience difficulties in individuation.

\section{References}

Abt, T. (2005/2007). Jungian psychological picture interpretation. (Translated by Lee, Yoo-kyung.) Seoul: Institute of Analytical Psychology.

Ackroyd, E. (1993/1997). The dream dictionary. (Translated by Kim, Byeongjun.) Seoul: Korea Psychotherapy Institute.

An, E-S. (2014). The analytic meaning of the volcano as a symbol of the creative eruption of emotions and psychic rebirth in sandplay therapy. Journal of Symbols and Sandplay Therapy, 5(2), 77-87.

Choi, M-J, (2013). An analysis of the mineral and rock units in science textbooks of elementary and middle school focused on the problem and the improvement. Master's thesis at the Graduate School of Education Korea University.

Chong, E-C, (2014). Inner visualization of a stone's accumulation feature. Master's thesis at the Graduate School of Ewha Womans University. 
An Eun Sun / Rock: Symbol of Self in the Process of Individualization - Alchemy Transformation in Sandplay Therapy-

Cooper, J. C. (1978). An illustrated encyclopedia of traditional symbols. New York: Thames \& Hudson. (Trans. Korean into 1994).

David, F. (1993). The language of symbols. (Translated by Choi, Seung-ja.) Seoul: Munhakdongne.

Edinger, E. (1984). The creation of consciousness: Jung's myth for modern man. ()Toronto: Inner

City Books. (Trans. Korean into 2016).

Edinger, E. F. (1991). Anatomy of the Psyche. La Salle, IL.: Open Court.

Fideler, D. (2014). Restoring the soul of the world: Our living bond with

natures intelligence. Rochester, VT: Inner Tradition.

Han, G-Y, (2007). The symbolism of cave in tales. Master's thesis at the Graduate School of Education Korea University.

Harris, J. (2001). Jung and Yoga: The Psyche-Body Connection. Toronto: Inner City Books.

Hawthorn, N.(1988). Big rock face. (Translated by Lee,Joon-yeon.) Seoul: Woongjin Publishing.

Jang, M-K. (2017). Analytic psychological sandplay therapy. Seoul: Hakjisa.

Jung, C. G. (1934). Personality and Transference. CW 3. Princeton: Princeton University Press (Korean trans. 2004)

Jung, C. G. (1964). Man and His Symbols. (Trans. Into Korean, 2013).

Jung, C. G.(1985). Erlosungsvorstellungen in der Alchemie. Princeton: Bollingen/Princeton University Press. (Trans. into Korean in 2004).

Jung, C. G. (1985b). Traumsymbole des Individuationsprozesses. (Trans. into Korean in 2004).

Kim, J-H, (2010). A psychological study of art therapy through the color. Master's thesis at the Graduate School of Education Kangwon National University.

Kim, S-J, (2003). Study on the image structure of cheongma Yuchi whan's poetry. Master's thesis at the Graduate School Yonsei University.

Lee, K-H, (2005). The study on development relation of self-differentiation and identity formation in the women of middle age. Master's thesis at the Graduate School Seoul Women's University.

Lee, N. K. (2016). Candlelight: symbol of consciousness in holy protective space. Journal of Symbols and Sandplay Therapy, 7(2), 73-88.

Mittford, M. B. \& Wilkinson, P. (2008/2010). Signs and Symbols. Paju: Book 21 Publishing Co.

Mircea, Eliade. (1976/2005). Histoire des croyances et des idees religieuses. Paris. Neumann, E. (1974). Die Grosse Mutter. Patmos Verlag GmbH \& Co., KG. (Trans. Korean into 2007).

Park, H-J, (2012). Chaos, death and rebirth in the process of sandplay therapy for child. Doctoral 
Journal of Symbols \& Sandplay Therapy, Vol.12 No.1.

dissertation at Myongji University Graduate School.

Rhi, B-Y. (2004). Self and Self realization. Seoul: Hangilsa.

Robert, A. J. (1989/2006). Femininity "She" read as a myth. (Translated by Go, Hye-kyung.) Seoul; Dongyeon.

Shin, M-K, (2013). Alchemic transformation in the process of sandplay therapy for unmarried mothers.

Doctoral dissertation at Myongji University Graduate School.

Turner, B. A. (2005/2009). The handbook of sandplay therapy. Los Angeles, CA: Temenos Press.

von Frantz, M-L. (1981). Puer aetemus. Munchen: Sicago Press.

Weinrib, E. L. (2004). Images of the Self. The sandplay therapy process. Cloverdale: Temenos Press. (Original work published 1983).

Yoo, C-H, (2002). Book of life. Seoul: Miresa.

Yoo, S-Y. (2016). Millstone: the creation of a new coalescence consciousness of opposites. Journal of Symbols and Sandplay Therapy, 7(1), 47-64.

Web sites

Nativity Scene(2021, Jan 20). Retrieved from

https://www.google.co.kr/search?q=nativity + scene\&tbm =isch\&tbo.

Diamonds are forever(2021, Jan 20). Retrieved from

http://www.naturehistory.org/2016/09/blog-post.html.

투고일 : 2021. 03. 30

수정인 : 2021. 05. 17

게재확정일 : 2021. 07. 01 


\title{
바위: 개성화 과정에서 출현한 자기(Self)의 상징 - 모래놀이치료과정에서 나타나는 연금술적 변환 -
}

\section{Rock: Symbol of Self in the Process of Individualization \\ - Alchemy Transformation in Sandplay Therapy -}

\author{
안 은 선
}

An Eun Sun

\begin{abstract}
$<$ Abstract $>$
This study investigated the process leading to individuation by examining the symbolism of rocks that emerged from sandplay therapy for a middle-aged woman from the perspective of analytical psychology and alchemy. The rock symbolizes an unchangeable life force, nurturing, recovery, source of living water, grave, and place in contact with spiritual energy. The alchemical process of creating new substances using existing substances proceeds in the order of calcification, dissolution, solidification, sublimation, decay, separation, and unity. In this study, the client expressed her unconscious through the rocks in the sand tray, which corresponded to the calcification of alchemy. Afterwards, the client expressed feelings such as despair and sadness that existed deeply within her, which were linked to the process of dissolution and coagulation of alchemy. Finally, the client could proceed with the process of individuation through self-integration with her shadow by accepting the suppression and wounds of her heart that were suppressed for a long time in consciousness, which is connected with the process of sublimation, corruption, separation, and unity in alchemy. The process of individuation involves completing the true Self by integrating the Self that exists inside the individual. We can integrate these processes through a confrontational dialogue between consciousness and the unconscious through symbols.
\end{abstract}

Keywords : Self, rock, alchemy, individualization, analytical psychology

* 남서울대학교대학원 아동복지학과(아동상담·심리치료전공) 박사수료 (pre-woman71@hanmail.net) 
Journal of Symbols \& Sandplay Therapy, Vol.12 No.1.

\section{I. 서 론}

오랜 옛날부터 인간은 특정 바위를 보고 그 바위에 영혼이나 정신이 깃들어 있다고 생각 하였다. 그러한 바위들은 형태가 사람의 얼굴 윤곽을 닮은 태고의 선돌(menbir)이라든지 그리 스 신의 두상처럼 인간의 모습을 닮은 것들이 많다. 이처럼 바위에 어떤 생명을 불어넣어 의미를 부여하는 것은 인간의 내적 무의식을 그 바위에 투사하는 것이라고 설명할 수 있다 (Jung, 1964/2013). 사람들은 자신의 내적 자아 상태와 연결되어지는 대상에 대해 동일시하 려는 무의식적 동기를 갖는다.

인간은 먼 옛날부터 바위에 대해 심리적으로 중요한 상징적 의미를 부여해 왔다. 원시인 들의 경우 가공되지 않은 자연석을 정령이나 신의 거처로 믿기도 했고 묘석이나 경계석 등 을 종교적인 숭배의 대상으로 삼아 왔다. 그것은 동물 그림이 그려진 동굴이나 암벽 등에 대해 수세기에 걸쳐 많은 사람들이 종교적 성소로 여겨져 온 것으로도 알 수 있다(Jung, 1964/2013). 만약 일반적인 어떤 다른 장소에 동물 그림이 그려져 있었다면 사람들은 크게 의미를 부여하지 않았을 수도 있다. 하지만 바위가 주는 상징적 요소가 사람들의 내면에 신앙과 숭배적 느낌을 야기했다고 볼 수 있다.

바위는 여러 가지 상징성을 가지고 있다. 바위는 양육하는 장소, 영적인 에너지와 접촉하 는 장소, 회복, 생수의 근원, 저항할 수 없는 힘, 인간에 대한 표현, 무덤, 생명력과 영성에 대한 상징이며 그리고 인간의 정신 가운데 가장 오래된 무의식적인 부분으로 자기의 토대 나 본질을 상징한다(Ackroyd, 1993/1997). 바위에 대한 상징적 의미는, 그 내면에 신성하고 본질적인 것을 품고 있지만 그것의 추출을 위해서는 깨어지고 갈아지는 연단을 거쳐야 하 는 것을 의미하고 있으며, 이는 바로 인격의 개성화과정에 비유될 수 있는 상징이다. 이는 개성화가 한 두 번의 결과로 얻어질 수 있는 것이 아니라 일련의 과정이 필요한 것이기 때 문이다.

개성화는 개인이 갖고 있는 한계와 어려움을 극복하며 개인의 독특함을 발전시키고 통합 하는 과정이다. 다시 말해 사람이 진정한 자신이 누구인가를 발견하는 것이다. 이 과정은 상징을 통한 의식과 무의식 간의 직면적인 대화를 통해 통합된다(장미경, 2017). 어떤 의미 에서 개성화는 자기(Self) 속에 있는 대극적인 요소들을 갈등 속에서 인식하게 되고 결국 수 용을 통해 자기의 통합으로 이끌어 가려는 시도이다.

Jung이 개성화(individuation)라고 부른 전체성을 향한 인간정신의 발달 과정은 연금술로 상 징될 수 있는데, 연금술사에게 순수한 금을 추출해내는 과정에 필요한 용기(容器)는 대지모 (大地母) 여신의 자궁과도 같다. 이 용기 안에서 물질의 순환과 변환과정이 일어나며, 이 과 정에서 연금술사는 화학적 변환의 비밀을 꺼내려는 진지한 노력을 기울인다(장미경, 2017;

Fideler, 2014). 
본질적으로 연금술은 불순한 금속 덩어리를 순수한 금이나 은으로 바꾸려는 시도이며, 그런 뜻에서 연금술은 무지에서 깨달음으로 향하는 영적 여정을 상징하기도 한다(Miranda 외, 2008/2010). 연금술사는 기존의 재료를 통해 하나의 새로운 형상 특히 금과 같은 궁극적 물질을 창조해 나가고자 한다. 이 과정에서 연금술사는 자신의 내면에 발현된 수많은 방법 을 가지고 반복된 실험을 통해 원하는 물질을 만드는 작업을 한다. 이것은 연금술에서 정 신적 가치를 의미하는 현자의 돌(philosopher's stone)을 찾는 작업이며(신미경, 2013), 이러한 과정은 개성화 과정에서 자신의 단단한 한계와 틀을 깨트리고 넘어서서 새로운 자기로 발 전해 나가는 개성화 과정과 같다.

연금술적 변환의 과정이 물질에 연금술 정신을 투사(projection)한다는 측면에서, 정신을 상 징에 투사하는 심층 심리치료와 맥을 함께 하며, 이 과정에서 수용적이고 지지적인 치료자 의 변함없는 태도가 내담자 변환의 중요한 요소로 작용한다. 이러한 치료자의 안전한 토대 위에서 내담자는 이전에 알지 못했던 새로운 것 또는 무의식의 대극을 합일시키게 된다(von Frantz, 1981). 모래놀이치료과정에서 내담자는 치료자라고 하는 안전한 보호 안에서 자기 자신이 연금술사가 되어 자신의 문제를 바위에 투사하고 그것을 통해 자신이 진정으로 원 하는 소망을 이끌어 낸다.

모래상자에 나타난 바위는 다양한 상징적 의미로 사용되는데, 영속성, 안정성, 신뢰성 등을 의미하기도 하고, 경직됨, 차가움, 딱딱함을 상징하기도 한다(Cooper, 1978/1994). 이러 한 상징은 모래상자 작업을 하는 내담자의 심리적 현재 상태를 표현하기도 하고, 현재 상 황에서 벗어나기 위한 해결책으로서 미래적 소망을 나타내기도 한다. 특히 모래상자에서의 바위는 변화와 전환의 의미를 포함하기도 하는데, 내담자는 자신의 내면에서 너무나 단단 히 머물러 있는 어떤 문제나 상황에 대해 그것을 바위로 투영함으로서 결국은 그 바위가 깨트려져서 자신이 원하는 새로운 형상의 이미지로 창조되기를 염원한다.

본 연구는 이러한 바위의 특성 및 상징성을 통해 개성화 과정에서 나타나는 자기(Self)의 상징에 대한 이해를 설명하고, 이를 연금술의 변환과정과의 비교 적용을 통해 개성화 과정 을 나타내는 자기(Self)의 발전 과정을 더 명확히 제시하고자 한다.

\section{ㅍ. 바위의 특성 및 상징성}

\section{1. 바위의 특성}

바위는 천연무기질로 이루어진 고체로 훍이 굳어서 된 광물질의 단단한 덩어리이다. 자 연적으로 존재하는 소재 중 가장 견고하고 내구적이며, 그 무게나 압축 강도가 훍이나 나 
Journal of Symbols \& Sandplay Therapy, Vol.12 No.1.

무 등 다른 천연재료에서 볼 수 없는 성질을 가지고 있다. 바위는 조성된 과정 및 바위 성 분의 차이 그리고 지각변동 같은 환경적 특성에 따라서 바위를 이루고 있는 구성 물질, 조 직, 특성이 다양하게 나타나는데 일반적으로 크게 화성암, 퇴적암, 변성암 등으로 구분할 수 있다(정은지, 2014).

화성암은 마그마가 식어 만들어진 암석을 말하며, 밝은 색이 용암이 흐른 흔적을 나타낸 다. 퇴적암은 물과 바람 등의 운반작용에 의해 운반된 광물이 지표의 낮은 압력과 낮은 온 도 상태에서 퇴적작용을 거쳐 만들어진 암석을 말하며, 풍화와 침식에 의해 퇴적물이 만들 어지고, 중력에 의해 낮은 곳으로 이동되어 딱딱하게 굳어지면 퇴적암이 된다. 변성암은 열 과 온도, 화학적 활성기체나 액체에 의해 만들어진 암석을 말하며, 높은 온도와 압력을 받 은 암석은 새로운 화학조합이나 구조를 갖는 암석으로 변한다. 이때 변성작용을 받는 암석 은 액체상태가 아닌 고체 상태에서 변성이 일어난다(최민지, 2013). 이렇듯 화산활동 작용을 포함하여 풍화, 침식, 또는 높은 압력과 열작용에 형성된 바위는 시간이 지나면서 자연스럽 게 단단해지며, 오랜 시간을 거치면서 다양한 모습을 보여준다.

태초부터 자연 환경의 가장 근본이 되는 훍과 바람 및 화산 작용에 의해 때로는 수억 년 의 세월을 지나며 잉태된 바위는 자연의 신비로움과 경외감을 깊이 느끼게 한다. 하지만 바위도 분해의 과정을 거친다. 아무리 단단한 바위라도 비나 바람에 의해 부서져서 돌이 되고, 이 돌은 다시 부서져서 모래가 되고 마지막엔 다시 바위의 근원이 되었던 훍으로 되 돌아간다. 자연현상과 사물에 의미를 부여하기를 좋아했던 동양에서는 바위의 이러한 생성 과 해체를 통해 생명과 역사의 순환이라는 의미를 부여하기도 하였다(정은지, 2014). 자연에 서 태어나서 다시 자연으로 돌아가는 자연 순환적 원리를 담고 있는 것이 바위이다.

\section{2. 바위의 상징성}

\section{1) 모성 상징으로서의 바위}

바위는 산, 나무, 숲 등과 함께 우주의 전체성을 느끼게 하는 자연을 형성한다. 그래서 바위를 대지의 처녀성을 느끼게 한다는 뜻에서 영원한 어머니의 태반이라고 표현하기도 한 다(Robert, 1989/ 2006).

융은 창조와 탄생의 상징인 어머니의 원형을 나타내는 바위에 대해서 무의식을 상징한 산모라고 하였다(Jung, 1964/ 2013). 때때로 바위는 동굴의 형태로 나타나는데, 동굴은 은신 처를 뜻하는 여성의 자궁을 상징한다. 자궁은 탄생과 부활로 연결되어 우주의 중심으로 이 어진다. 동굴을 생명의 모태 상징으로 보는 견해는 초기 정신분석학자들에 의해서 많이 시 도되었으며, 양수 속을 헤엄치는 태아의 체험, 출생 관, 출생외상과 관련지어지면서 동굴이 자궁에 비유되는 정도가 높아졌다. 이는 동굴의 어둠, 아늑함이 모성의 신비와 그 자애를 
잘 말해주고 있기 때문이다(한기연, 2007 재인용). 분석적 의미로 볼 때, 동굴에 들어간다 함은 자신의 생명 근원인 어머니 뱃속으로 다시 들어가려는 욕구, 일종의 퇴행이라고 설명 할 수 있다.

성자를 안고 있는 성모 마리아의 초상화(Figure 1)는 성스러운 것과 직결되는데, 그림에서 성모 주변에 동굴, 석주, 바위가 나타난다. 예루살렘에 있는 신전의 바위는 위대한 모신을 나타내는 상징이다(Neumann, 1974).

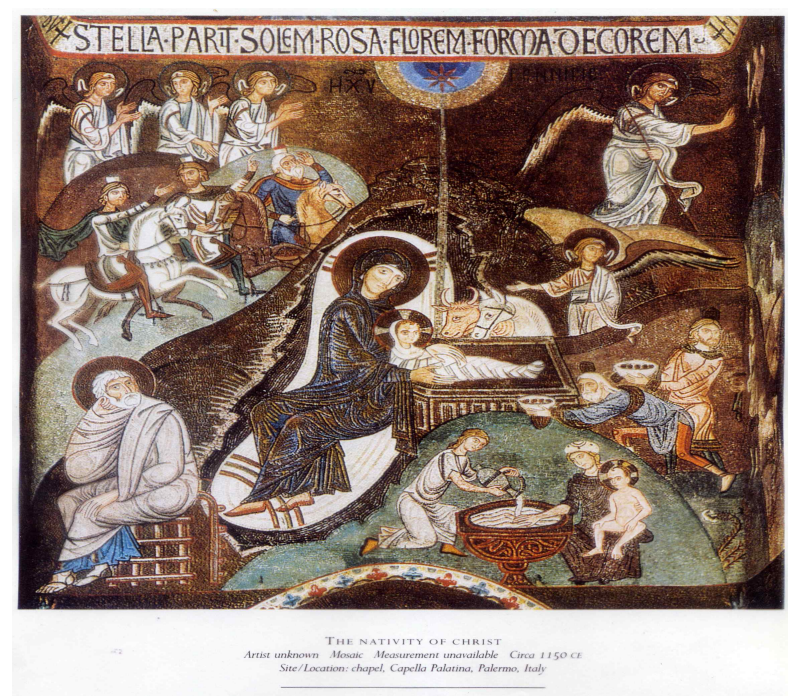

Figure 1. Nativity Scene

https://www.google.co.kr/search?q=nativity +scene\&tbm=isch\&tbo

\section{2) 변환의 상징으로서의 바위}

원소(element)는 물질의 기본 요소이며, 원소끼리 화학 결합한 것이 광물 (mineral)이다. 이 런 광물이 섞여 있는 것이 바위(rock)이다. 대부분의 보석은 세련되게 연마하거나, 다듬어서 그 아름다움을 돋보이게 하는데, 가공 이전에 있는 그대로의 바위를 원석(gem stone)이라고 한다. 보석 중의 보석이라 할 수 있는 다이아몬드는 가공 이전의 원석으로 볼 때는 그다지 아름답지 않다. 대부분 땅속에서 캐내며 평균 250톤의 훍을 파내서 다양하고 복잡한 과정 을 거쳐 1 캐럿의 순수한 다이아몬드 원석을 얻는다. 심지어 해마다 채굴되는 4000 만 내지 5000 만 캐럿 중에서도, 아주 적은 양만이 보석으로 적합하다. 이러한 원석이 장인의 손길을 통해 연마의 과정을 거쳐 가장 인기 있는 보석으로 태어나게 된다. 다이아몬드는 뛰어난 아름다움으로 인해 오랫동안 사랑을 받고 있으며 단단함으로 인하여 여러 도구와 기계류에 널리 사용된다(http://www.naturehistory.org/2016/09/blog-post.html). 불순물 덩어리인 원석에서 아 
Journal of Symbols \& Sandplay Therapy, Vol.12 No.1.

름다운 보석으로 변환되는 과정에 대해 드 베르빌은 [암호기법 수집록]에서 다음과 같이 말 하였다(Jung, 1985 재인용).

만일 누구든 가끔 유향 소량을 변환시키고 그것을 압착하여 투명한 눈물로 유향 수지 점액을 추출하기를 원한다면 그로 하여금 주의를 기울이게 하라. 그러면 그는 고정된 시간에 순한 불의 압력 하에 철학적 질료로부터 유출된 실체 같은 것을 관 찰할 것이다. 왜냐하면 그의 검은 보라색이 두 번째로 자극하자마자 거기서 마치 하나의 물방울, 혹은 꽃, 진주, 보석과 같은 것들이 생기게 될 것이다. 그것은 매우 투명한 흰 빛 안에 흐르기까지 가지각색으로 다양해질 것이다. 그리고 그 후에 철 학자들의 혼과 빛의 참된 불인 아름다운 홍옥(루비)과 천상의 돌의 영광으로 장식 될 것이다.

바위 속에 있는 원석은 그 자체로는 가치가 없는 단순한 돌일 뿐이다. 하지만 장인의 중 단 없는 연마과정을 통해 원석은 마침내 다이아몬드, 홍옥, 진주와 같은 아름답고 가치가 높은 보석으로 변환된다.

\section{3) 견고함과 의지의 상징으로서의 바위}

바위의 단단함은 하루아침이나 단기간이 아닌 오랜 세월을 지내면서 형성된다. 그 과정 에서 비, 바람 등과 같은 자연현상을 견디어 낸다. 그래서 바위는 오랜 세월을 견디어 낸 그 단단함에서 견고함과 영속성을 느끼게 해 준다.

이러한 바위에 대해 시인 청마 유치환은 삶을 담아내는 의미로서 불변성, 지구력, 고통 및 고통을 초월하는 의지 등을 시(詩)로 표현하였다(유치환, 2002).

바위

내죽으면 한 개 바위가 되리라.

아예 애련에 물들지 않고

희로(喜怒)에 움직이지 않고

비와 바람에 깎이는 대로

억년 비정(非情)의 함묵(緘默)에

안으로 안으로만 채찍질하여

드디어 생명도 망각하고

흐르는 구름

머언 원뢰(遠雷) 
안은선 / 바위: 개성화 가정에서 출현한 자기(Self)의 상징 - 모래놀이치료가정에서 나타나는 연금술적 변환-

꿈꾸어도 노래하지 않고

두 쪽으로 깨뜨려져도

소리하지 않는 바위가 되리라.

<생명의 서 中>

유치환의 시에서 바위는 무엇보다도 감정에 흔들리지 않는 강인함을 상징한다. 그것은 인간 사(事)에서 발생되는 애정과 번민에 흔들리는 일이 없으며, 기쁨이나 성냄이나 하는 것들에도 움직이지 않는다. 바위는 비와 바람을 맞으면서도 모든 것을 묵묵히 견디어 내는 비정함 속에서 자신의 단단함을 지킨다. 유치환은 이러한 모습을 의인화하여 안으로 안으 로만 채찍질하여'라고 노래한다. 그리하여 바위는 마침내 모든 흔들림을 초월하고 극복하는 경지에 도달한다. 또한, 바위는 고통과 역경을 극복하는 극한의 인내력을 담아내는데, 바위 는 두 쪽으로 깨어질지라도 소리 내지 않는, 굳은 의지 그 자체로 형상화된다. 이것은 어떠 한 상황에도 굳은 의지를 관철하고자 하는 인간의 의지를 바위를 통해 나타낸 것이다(김수 정, 2003).

때로 자연에서 인간의 형상을 닮은 바위를 발견할 수 있는데, 사람들은 그러한 바위에 대해 경외와 생명을 불어넣고 투사하여 영원한 사랑이나 우정과 같은 정신세계의 영원성과 연결시키기도 하였다(Jung, 1964/ 2013). 그래서 그러한 바위를 주제로 한 소설이 등장하고 그러한 바위에 대한 경외감을 갖거나 마음의 소원을 비는 신앙의 대상으로 삼기도 한다.

\section{III. 물질의 변화과정에 따른 연금술적 단계와 모래상자에 나타난 바위의 변화과정}

Jung에 따르면 연금술의 특성은 영혼의 본질을 찾아가는 길에 내면의 본성을 외부로 끌 어내는 작업과 유사하며, 이는 무의식 속에 숨겨져 있는 자신의 가장 고귀하고 자연스러운 가치를 무의식에 그대로 가라앉게 내버려두지 않고 그것들을 발견해 내는 것과 같다고 하 였다(이나경, 2016 재인용).

연금술 변화는 연금술의 내적 물질과의 대화이며 인간의 정신을 물질에 투사하는 과정이 라고 할 수 있다(유세연, 2016). 연금술 과정에 있어서, 물질은 변화를 위해 깨어져야 하며, 깨어진 물질에 새로운 요소가 추가되거나 혼합되어야 한다. 또한 이러한 요소들의 해체와 섞임을 담아내는 크고 견고한 용기(vessel)가 있어야 한다. 이는 심리적 정신의 변화에 있어 서, 기존구조가 온전히 분석되어 새로운 태도, 새로운 경험, 새로운 조망이 이전 것에 추가 되는 것과 같다(장미경, 2017). 이런 측면에서 연금술의 변화 과정과 심리적 변화과정은 그 
Journal of Symbols \& Sandplay Therapy, Vol.12 No.1.

근원적 의미와 진행과정에서 유사함을 가진다.

Edinger(1984/2016)는 석회화, 용해, 응고, 승화, 부패, 분리, 합일 등의 7 가지 작업과정을 통해서 연금술의 변환과정을 설명하고 있는데, 내담자의 모래상자에서도 자신을 온전한 인 간으로 통합하려는 변환과정으로서 이와 유사한 과정이 진행된다고 보았다. 일반적으로 연 금술에서의 물질은 수난 받고 죽어서 새로운 존재 양상으로 재탄생 한다. 즉, 수난의 통과 의례 기능을 물질에 투사하여 고통과 죽음과 재생에 상응하는 연금술 조작에 의해 물질은 보석이 된다(Mircea, 1976). 본 연구에서는 이러한 연금술 과정과 비교하여 중년 여성의 내담 자 모래상자에 출현한 자기(Self)의 상징인 바위를 통해 분석심리학과 연금술적 변환관점에 서 살펴보고자 한다.

내담자는 40 대 중년여성으로서 자라면서 애착의 문제가 잘 해결되지 않아 결혼 후에 가 족 안에서 자기정체성에 혼란을 느끼고 있었고 대인관계에서의 어려움을 호소하고 있었다. 내담자를 대상으로 한 모래놀이치료는 총 12 회기로 진행하였으며, 회기가 진행됨에 따라 내담자의 문제는 나선형구조로 노출과 해결이 반복되는 형태로 나타났다.

\section{1. 석회화(사랑의 불에 대한 열정과 목마름)}

석회화(calcinatio, burning)의 연금술적 의미는 강력한 열기 때문에 물체가 말라 버리거나 타 버리고 새로운 형태로 변화하는 것을 말한다. 연금술의 이 단계는 모래상자에서 타오르 는 불, 열기나 먼지 등으로 나타날 수 있다. 심리적으로는 기존에 자아가 가지고 있던 흥미 나 관심사가 말라 버리거나 타 버리고 우울이나 공허감을 느낀다. 또한 좌절되고 억압된 열정, 혹은 열망과 자아 사이에 갈등이 강화되거나 가열되기도 한다(장미경, 2017).

모래상자의 이 단계에 대해서, 노이만(Neumann)은 어둠, 검음, 죽음, 갈등, 두려움 등과 관련된 상징들이 나타나는데 이러한 상징들은 아직 분화되지 않은 대모(Great Mother)와 아 들의 상징이며 자기(Self)로부터 분화되지 않은 자아(ego)의 씨앗 상태라고 하였다(신미경, 2013 재인용).

이 단계에서 내담자는 자신의 답답한 내면의 감정 상태와 자아에 대해 다음과 같이 말하 였다.

“이 바위가 나에게 답답한 느낌과 숨이 막히는 느낌을 주어서 나는 이 바위가 보기 싫어요. 내가 어렸을 때 바위 틈에서 뱀이 튀어나왔을 때가 떠올라요. 길가에 두 개의 바위 사이를 지날 때 사탕이 목에 걸려서 죽을 뺀했어요. 나는 커다란 바 위에 매우 집중했고 흥분되어 모래 상자 안에 있는 다른 것들은 눈에 보이지도 않 아요." 


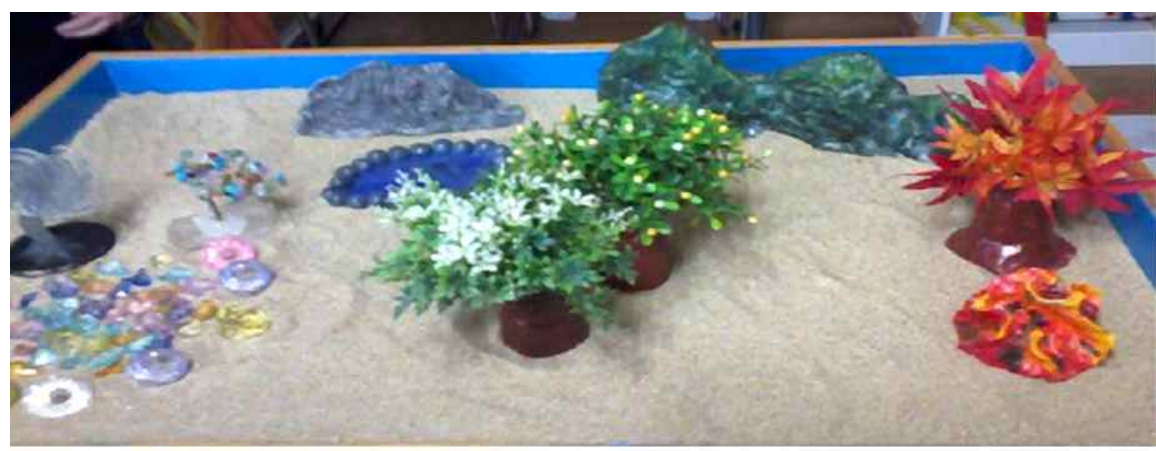

Figure 2a. First picture of sand play

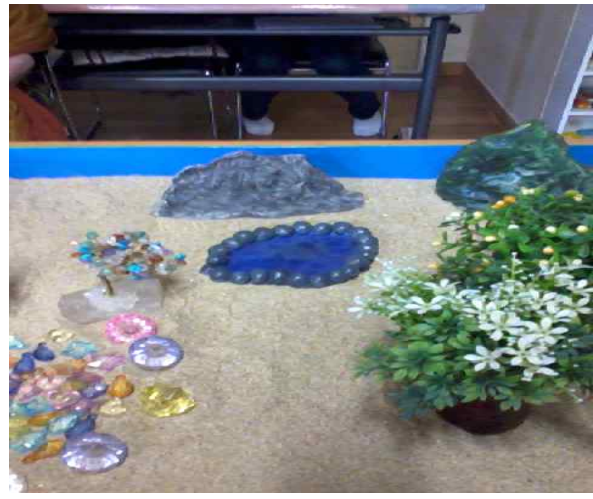

Figure 2b. Unpleasant rock

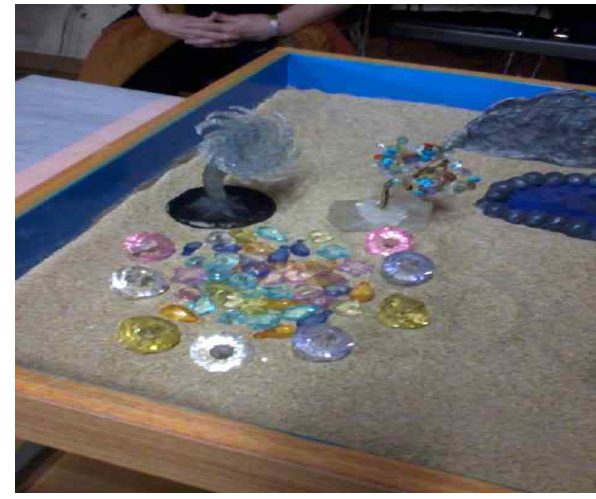

Figure 2c. Jewels in the Unconscious

모래상자에 나타난 바위는 일반적으로 경직되고 차갑고 딱딱함을 상징하는데Cooper, 1978/1994), 내담자가 표현하고 있는 바위는 내면의 미해결과제로 인한 답답함과 더 나아가 고 싶은 자아의 옥구에 대해 그렇지 못한 현실의 감정을 표현해 주고 있다. 이는 내담자의 변화 옥구가 그렇지 못한 현재의 상태에 대해 불일치감을 정서적으로 표현한 것이라고 볼 수 있다.

또한 바위 옆에 놓여있는 열이나 불과 관련된 화산은 내담자의 분화되지 않은 혼돈의 상 태, 분노의 감정을 상징하여 자아의 퇴행적 죽음의 단계를 보여 준다. 이러한 모래상자에서 보여지는 내담자의 심리적 특징은 자아의 주도적 역할이 낮아져 무의식 상태에 의존하여 자아가 중지된 상태이다. 또한, 퇴행, 우울, 불안, 분노, 화, 후회, 죄책감, 부정적 감정이 표 현된 것으로서 내담자가 알지 못하는 혼돈의 심리적 상태를 표현하였다. 모래상자에서 나 타나는 불의 상징적 의미는 분노의 불길이기도 하지만 의식의 불로도 볼 수 있으며(안은선, 2014), 또 다른 심리학적 측면에서 볼 때 불에 대한 상징은 열정의 열기 또는 의식의 빛으 
Journal of Symbols \& Sandplay Therapy, Vol.12 No.1.

로 묘사된다(Cooper, 1978/1994).

이 단계에서 내담자는 모래상자 안에 놓은 바위와 불꽃을 통해, 내담자의 내면세계에는 답답함, 혼돈, 불안, 분노, 화를 비롯하여 열정과 의식의 빛도 존재하고 있음을 보여준다.

\section{2. 용해 (자기를 찾기 위한 고통과 울부짖음)}

용해(solutio, dissolving)의 연금술적 의미는 고체가 액체로 변하거나 입자로 분쇄되는 과정 을 말하며, 이 상태는 모래상자에서 흐르는 물, 홍수, 비 등으로 상징화될 수 있다. 심리적 으로는 자아가 자기방어적인 능력을 상실하는 것을 의미하는데, 자아가 더 넓고 보다 포괄 적인 관점을 재형성하기 위해, 밖으로만 향하던 에너지가 내면의 무의식으로 들어가고 새 로운 자아의 체계를 형성하기 위한 에너지를 얻는 과정이라고 볼 수 있다.

이 단계에서는 오래된 자아의 패턴 즉 상황 또는 요소 등의 제거(elimination)가 진행되며, 이 과정에서 낡은 태도는 씻겨져 나가고 정화(purified)되어 가치 있는 태도와 행동은 남게 된다. 모래상자에서는 이 과정에 대해 씻음, 닦음, 목욕, 소변보기 등과 울거나 비탄을 표현 하는 소품을 사용하며 딱딱한 감정의 이완, 울기와 관련된 상징이 나타난다(장미경, 2017).

이 과정에 대해 내담자는 자신의 답답한 내면의 감정 상태와 자아에 대해 다음과 같이 말하였다.

"이 늑대는 자신의 슬픔과 억울함을 신께 기도드리며 울부짖는 것 같아요. 저는 아들로 태어나지 못해서 억울했어요. 자신의 소중한 것을 지키기 위한 몸부림인 것 같아요."

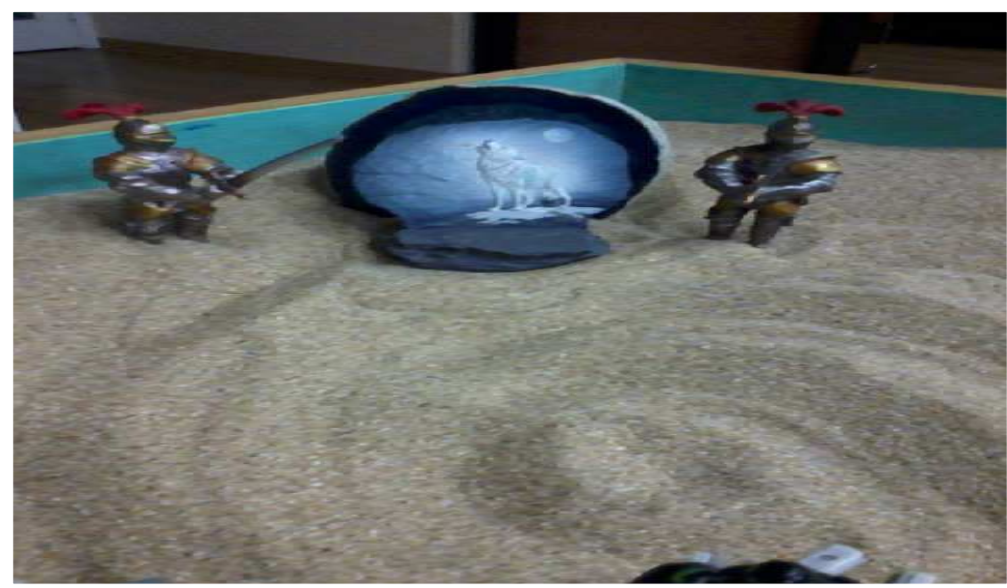

Figure 3. Rock with Wolf Howling and Two Guards 
“늑대는 자신의 슬픔과 억울함을 신께 기도드리며 울부짖는 것 같아요”라는 내담자의 말 은 내담자의 해결되지 않은 억울한 미해결 감정을 울부짖는 늑대의 마음에 투영하는 것으 로 나타나며, 이를 통해 그동안 쌓아두었던 심리적 벽이 깨어짐을 의미한다고 볼 수 있다. 즉 내담자는 새로운 자아의 탄생을 위해 기존의 불안전한 자아의 흐트러짐과 깨어짐을 경 험하고 있다.

Figure 3에서 내담자가 늑대 그림의 배경으로서 마노보석으로 표현하고 있는 것은 동굴이 다. 동굴 양쪽에는 병사들이 있어서 이 동굴을 지키고 있다. 이것은 마치 늑대로 투영되는 어떤 존재가 동굴 앞에서 동굴 안에 있는 것을 지키고 동시에 신에게 동굴 안의 존재 및 상황에 대해 알리는 듯한 느낌을 준다.

모래상자에 나타난 동굴(Caves)은 은신처를 뜻하며 자궁을 상징한다. 비어 있을 것 같은 동굴은 탄생과 부활로 연결되어 우주의 중심으로 이어진다. 동굴은 때로 암울한 느낌으로 서 지하세계, 지옥의 입구와도 관련되는데 주로 인간의 깊은 무의식과 연결된다(Miranda 외, 2008/2010). 또한, 동굴은 여성성의 상징이며, 세계의 심장, 무의식, 지하세계의 입구, 입문, 지혜를 나타내기도 한다(David, 1993). 본 모래상자에서 내담자가 보여주는 동굴의 상징은 아들로 태어나지 못한 억울함이 여성성에 대한 그림자로 상징되어 표현되었다.

바위에 새겨진 늑대는 양면적 상징을 가지고 있는데, 기독교 전통에서 늑대는 양을 잡아먹는 잔인함을 나태내지만 로마인들에게는 로물루스와 레무스(로마를 건국한 쌍둥이 형제)를 젖 먹여 키운 암늑대의 모성 본능을 상징한다(David, 1993). 또한 바위에 새겨진 늑대는 욕망이고 욕망은 불이다. 그래서 욕망은 스스로를 먹어서 소모시킨다. 이러한 지옥 을 방불케 하는 곳으로 하강한 후 자아는 불사조와 같이 다시 태어나 순수한 존재가 된다. 자아의 요구가 좌절된 바로 그 장소에서 자기(Self)의 전체성이 출현한다는 것을 암시하고 있다(Edinger, 1984/2016).

연금술에서는 용해의 과정을 통해 금을 둘러싼 불순물이 태워지거나 녹아지는 과정이 진 행된다. 모래상자에서도 늑대의 상징으로 표현되는 내담자의 슬픔과 억울함의 감정이 드러 나고 연소되어야 정화된 자기의 본질이 드러나게 된다.

이 단계에서 내담자는 자신의 문제가 노출되는 것을 통해서 억압되어진 자아의 새로운 성장을 바라는 마음이 나타난다.

\section{3. 응고 (재탄생되는 자기)}

응고(coagulatio, harding)의 연금술적 의미는 물체가 견고한 물질로 변화한다는 것이며 이 전에 의식에 없던 것이 구체적으로 새로운 형태를 취하게 되는 것을 말한다. 모래놀이치료 장면에서는 땅, 먼지, 진흙, 토양, 바위, 돌 같은 이미지로 나타날 수 있다(장미경, 2017). 


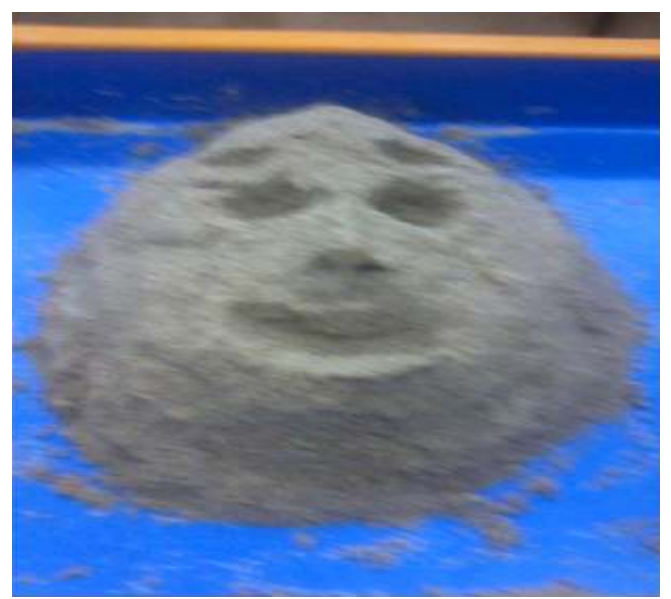

Figure 4. A large rock face

내담자는 자신이 진정으로 원하는 모습에 대한 바램을 물과 모래를 섞어서 다음과 같이 표출하고 있다.

"이것은 웃고 있는 사람의 얼굴이예요. 제가 바라는 큰 바위에 나오는 얼굴이예요. 제 얼굴 표정은 늘 굳어 있고 저를 보는 사람들은 저에게 화가 났냐고 묻곤 해요."

내담자가 진정으로 바라는 자기의 모습을 표현하기 위해 사용한 물은 형태도 없고 유동 적이며 고체, 액체, 기체로의 변환이 가능하며 모든 생명의 근원이다. 또한 물은 정화와 치 유작용을 하는 재탄생의 상징이기도 하다(박행자, 2012).

일반적으로 모래놀이치료과정에서 물의 사용은 자아의 의도적인 행위로 무의식에 직접적 이고 세밀하게 참여하는 것을 의미한다. 즉, 물의 접촉은 무의식과의 접촉에 대한 신뢰를 수반하고 물이 흡수되는 유동성은 자아를 자기에게로 안내하여 새로운 힘을 가져온다 (Turner, 2005/2009). 내담자가 물과 모래를 섞어 만든 큰 바위 얼굴은 내담자의 심리적 치유 와 재탄생의 상징으로 볼 수 있다. 내담자가 만든 큰 바위 얼굴은 내담자가 상상하는 완벽 하고 이상적인 것에 대한 상징이다(Hawthorn, 1988). 내담자에게 큰 바위 얼굴은 진정한 자 기(Self)를 찾아가는 여정을 안내하는 Psyche의 상징이다.

연금술에서 응고는 연금술사의 내적 세계를 충분하게 구체화 시켜가는 것으로서 고난을 포함한 변환작업의 하나이다. 모래상자에서 응고는 액체가 고체가 되고 납처럼 단단하게 되 며, 음식이 몸으로 흡수되어 신체의 일부가 되듯이 내담자의 진정한 내면의 옥구가 상징적 으로 구체화되는 주제를 담고 있다(Edinger, 1991). 더 깊은 측면에서 응고는 새로운 상황으로 변화를 위해서 숨을 고르거나 과녁에 화살을 던지기 위해 멈추는 순간과 같다(신미경, 2013). 
이 단계에서 내담자는 모래놀이상자에서 큰 바위얼굴에 자신의 진정한 욕구를 투영시켜 표현하고 있으며 그것은 곧 재탄생을 위해 잠시 멈추는 순간을 의미하기도 한다. 이것은 내담자의 내면에 있는 개성화의 욕구가 드러난 것이기도 하다.

\section{4. 승화(새로움을 위한 도약)}

승화(sublimatio, uplifting/inflating)의 연금술적 의미는 물질이 증류(distilation)과정에 의해 수 증기로 변화하는 과정을 의미한다. 모래놀이치료에 나타나는 이미지는 비행, 상승, 계단, 사 다리, 비행기, 새, 바람, 호흡 등이다.

승화의 심리적 의미는 더 넓은 조망(의미)을 얻기 위해 또는 새로운 가능성을 추구하기 위해 자아가 현재의 구체적 현실의 한계를 뛰어넘는 것이다. 부정적 측면에서 과장된 승화 는 현실로부터의 해리를 의미한다(장미경, 2017).

내담자는 새로운 자아에 대한 바램을 다음과 같이 하늘을 나는 독수리로 표출하고 있다.

"이 바위 앞에 있는 독수리는 새로운 삶을 위해 날아가려고 해요."

가공 이전의 있는 그대로의 바위가 가치 있는 보석이 되기 위해서는 본연의 모습이 깨트 려지고 연마되어야 하듯이, 바위 앞에 있는 독수리가 하늘을 마음껏 날아다니는 자신의 모 습대로 살기 위해서는 우선은 단단하고 날카로운 새로운 부리가 만들어져야 한다. 이를 위 해 독수리는 바위에 자신의 부리를 쪼아 깨뜨려서 새로운 부리가 나게 하며, 새로 나온 부 리로 자신의 예전의 날개를 뽑아내어 새로운 날개를 얻는다. 이렇듯 고통스러운 재탄생과정 을 감내하여야 하늘을 나는 독수리가 될 수 있듯이, 모래상자에서 내담자는 자신의 변화와 성장의 재탄생의 욕구를 독수리로 표출하고 있다. 내담자는 독수리의 모습을 통해, 새로운

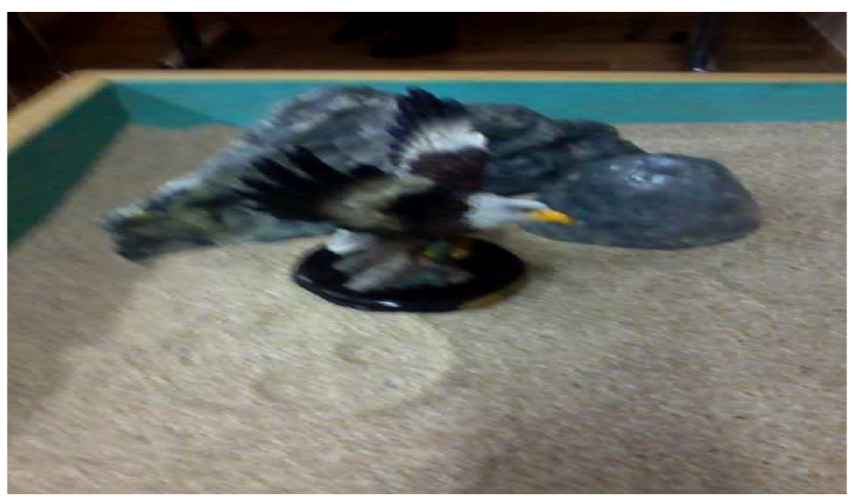

Figure 5. An eagle in front of a rock 
Journal of Symbols \& Sandplay Therapy, Vol.12 No.1.

삶을 살고자 하는 내면의 강렬한 옥구와 함께, 그러기 위해서는 자기로 하여금 날지 못하게 하였던 낡은 태도, 미성숙한 감정 표현, 좁은 시야 등을 버려야 하는 고통을 직면하게 된다.

연금술에서는 화학의 승화과정으로서, 열을 받은 고체는 곧바로 기체가 되어 연금술 용기의 꼭대기로 올라가고 차가운 층인 위쪽에서 다시 고체가 된다. 즉 승화는 상승의 옥구로서 위로 올라가는 것이며, 낮은 형태가 더 높은 형태로 변환되는 것과 관계가 있 다(Edinger, 1984/2016).

하늘을 높이 나는 독수리는 그 힘이 날개에 있으며 높이 오를수록 멀리 바라보게 된다. 그것은 좁은 시야의 자아가 더 넓은 세계, 더 높은 차원의 삶을 추구하는 것과 관계된다. 모래상자에서 내담자는 바위 앞에 독수리를 배치함으로써 현실적 문제로 답답한 자아가 더 높은 차원의 삶을 추구하고 있음을 상징으로 표출되고 있다(Robert, 1989/2006)

이 단계에서 내담자는 독수리의 강인함, 자유로운 날개 짓, 멀리 바라볼 수 있는 눈 등을 통해 자신의 현실극복과 자아의 성장에 대한 소망을 표출하고 있다. 이것은 내담자가 자신 의 자아의 성장을 통한 개성화를 발전시키고자 하는 소망이 있음을 알 수 있다.

\section{5. 부패(새로움을 위해 과거를 벗어 버림)}

부패(mortificatio, killing/dying)의 연금술적 의미는 물질의 죽음 또는 소멸(annihilation)을 의 미하는 부패(putrefactio)이다. 모래놀이치료에서는 시체, 무덤, 관, 총으로 쏘기, 칼로 찌르기, 죽이기, 묻기, 변 같은 배설물 등으로 나타날 수 있다. 이러한 감정상태의 심리적 의미는 자아 또는 자아 콤플렉스가 자기(Self)에 의해 변화되기 위해 죽임을 당하는 것이다. 부정적 인 측면에서는 억압이나 억제를 상징할 수도 있다(장미경, 2017)

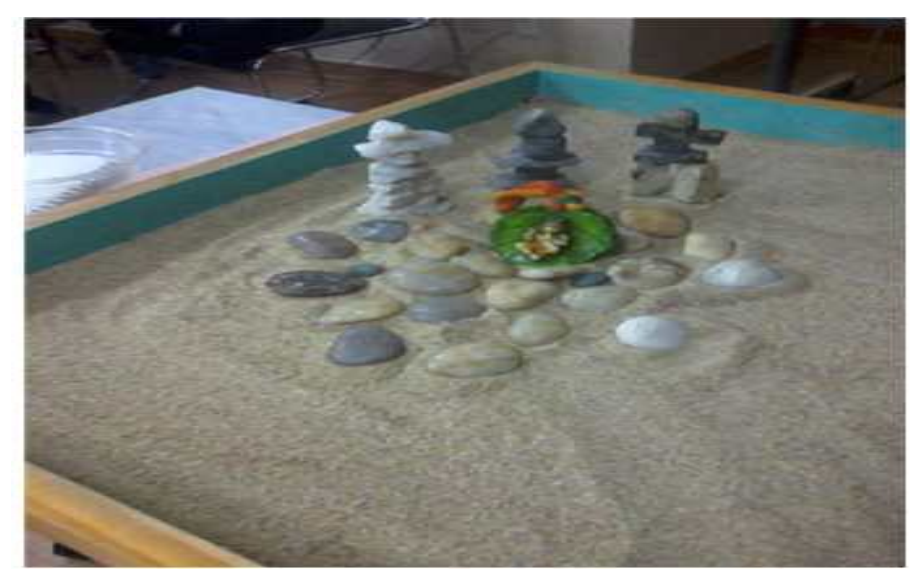

Figure 6. Krishna on a rock backed by cut stone towers 
안은선 / 바위: 개성화 가정에서 출현한 자기(Self)의 상징 - 모래놀이치료가정에서 나타나는 연금술적 변환-

내담자는 새로운 자아의 탄생을 위해 자신의 내면에서 죽고 사라져야 할 모습을 다음과 같이 고인돌로 나타내었다.

"뒤에는 고인돌이고 나에게 있어 죽어야 하는 것은 나와 타인에 대한 부정적 생 각, 좌절감, 비난 등 이예요."

내담자의 모래상자에서 바위 위에 놓인 비슈누 신은 인간을 대우주로 상징한다. 비슈누 의 화신들 중 가장 사랑받고 가장 인간적인 화신인 크리슈나는 세계를 상징하는데 그 상징 의 표상으로 원반, 고둥, 연꽃, 곤봉을 들고 있다(David, 1993). 신이 등장하는 것은 내담자가 자신이 새롭게 되는 것이 신의 도움, 은총과 연결되어 있음을 표출하고 있다.

내담자 모래상자에 나타난 고인돌은 죽음을 상징한다. 죽음은 부패와 관계있는 것으로 비탄과 슬픔으로 고통 받는 것이다. 내담자에게 있어 죽어야 할 것은 자신의 그림자로서 의식의 뒷면에 존재하는 여러 가지 부정적 요소들이다. 그것은 마치 어두운 창고에 내어 버려진 곡식이나 연장과 같은 것으로서 오래 두면 곰팡이가 피고 녹이 슬게 된다. 즉 의식 될 기회를 잃었으므로 미분화된 채로 남겨진 심리적 특징들이다.

인간의 생명은 곡식처럼 순환과정을 거친다. 곡식은 생명을 소유하였다가 죽어서 파종된 씨앗의 운명을 공유하고자 하는 희망을 가지고 대지모신의 태내로 되돌아간다. 그러나 곡 식의 죽음은 사라짐이 아니라 새로운 탄생의 씨앗을 위한 것으로서 바위처럼 강하고 파괴 되지 않는 존재이다(Robert, 1989/2006).

연금술에서 새로운 물질의 탄생을 위해서는 기존의 물질의 질서가 산산조각으로 깨트려 지는 과정을 거친다. 본 모래상자에서 내담자는 고인돌을 통해 자신의 열등한 인격을 창고 에 그대로 내버려두지 않고 죽음으로써 새로운 생명의 탄생을 소망하고 있음을 발견할 수 있다. 그것은 곧 자신의 내면에 있는 그림자를 수용하여 성장의 에너지로 전환시키는 개성 화 성취와 관계된다.

이 단계에서 내담자는 자신의 개성화를 더 높은 단계로 진행시키고자 자아성장과 개성화 발달에 방해가 되는 내면의 요소를 해결하고자 하는 욕구를 가지게 되었음을 알 수 있다.

\section{6. 분리(새로운 '나'의 발견)}

분리(separatio, separating)의 연금술적 의미는 혼란된 또는 낮은 수준의 물질이 혼합되어 있다가 분리되어 더 순수한 물질의 조합이 이루어지는 것으로서, 용해와 유사한 과정이지 만 좀 더 명확한 단계라고 할 수 있다. 모래놀이치료에서는 칼, 자르기, 찢기, 분류하기, 접 기, 배열하기, 두 가지 중 선택하기, 떠나기, 거리두기, 나누기, 이혼하기 등의 이미지일 수 
Journal of Symbols \& Sandplay Therapy, Vol.12 No.1.

있다. 이것의 심리적 의미는 부모를 비롯한 사람, 집단의 가치, 콤플렉스 등과의 과잉 동일 시로부터 자아가 분리되는 과정을 의미한다(장미경, 2017).

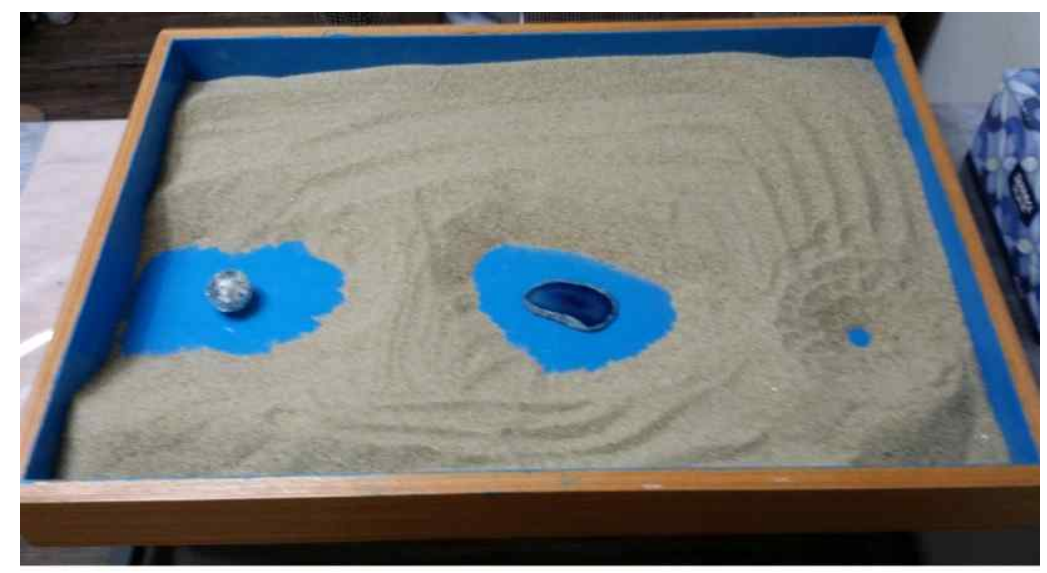

Figure 7. Separating

내담자는 새로운 자아의 성장을 위해 찢어진 종이 위에 보석을 놓아 다음과 같이 표현하 였다.

"가운데는 마노석이 끌려서 가져왔어요. 왼쪽 볼은 빛이 나니 끌려서 놓았어요.

내 마음 깊은 곳에 이런 보석과 같은 것이 있을 것 같다는 생각이 들어요."

내담자의 모래상자에 나타난 마노 보석의 상징에 대해 고대 문화에서는 이것을 지니면 눈에 보이지 않는 존재로 변한다고 믿었다. 마노 보석은 용기, 장수, 번영을 상징하는 것으 로서, 과거에는 풍요로운 수확을 기원하기 위해 황소의 뿔에 마노를 매달곤 하였다.

내담자는 모래상자에서 공간을 구분하여 푸른 바닥을 드러나게 하였는데, 이러한 상징을 통해서 내담자는 이전의 자아에서 분리된 새로운 자기(Self)를 찾아 떠나는 여정을 표출하고 있다.

모래상자에서 분리작업은 죽음의 상징성과 밀접한 관계를 가진다. 분리가 죽음으로 경험 될 수 있기 때문이다. 이것은 바위에서 영(spirit)을 추출하거나 몸체에서 정신(soul)을 추출하 여 내는 것에 해당한다. 그렇게 되면 정신의 내용물의 구체적인 현현인 이전의 몸체는 죽 게 된다(Edinger, 1984/2016).

내담자는 모래상자 왼쪽에 은색의 알을 표현하였는데, 연금술에서 알은 연금술사에 의해 포착된 혼돈, 즉 그 안에 세계 혼을 묶어둔 기본 재료를 의미한다. 둥근 솥으로 상징되었던 
알에서부터 독수리 또는 불사조 같이 이제는 자유로워진 심혼이 솟아난다. 그것은 육체 속 에 갇혀 있던 안트로포스와 결국 다시 동일시 된다(Jung, 1985b).

내담자의 오른쪽의 모래상자에 표현한 손자국은 마치 네팔 순례자의 길, 깨달음의 길처 럼 자아가 과거의 모호한 자아와 분리되어 앞으로 가야할 새로운 창조적이고 성장적인 미 래의 여정을 분명하게 흔적으로 표출하고 있다. 이 단계에서 내담자의 개성화 발달을 위한 옥구가 더욱 강렬해지고 내적자아가 더욱 정교화 되어지는 것을 볼 수 있다.

\section{7. 합일(Self인 보석의 출현, 통합된 자기 발견)}

합일(conjunctio, joining, uniting)의 연금술적 의미는 이전에는 별개였던 두 개의 물질이 새 로운 물질을 창조하기 위해 연합하는 것을 의미한다. 이 단계는 모래상자에 상징적으로 함 께 융합하거나 다른 것으로 변화하는 피겨들, 물리적 접촉 등으로 상징화될 수 있다.

합일은 조화를 이루고 연결하고 대극을 합치시키는 작업, 최상의 성취를 통해 현자의 돌, 금을 얻는 것이며. 보석, 금과 같은 귀중한 보물, 만다라, 성스러운 소품. 내적 외적 갈등 해결 조화로운 통찰력이 표현된다고 할 수 있다(장미경, 2017).

모래상자에서 적절한 양의 물이 사용되었는데 물은 재탄생으로 생명수, 우물, 식수, 강, 바다 그리고 세례 등으로 표현된다. 이는 내담자가 미지의 것으로 나아가는 자아의 의도적 인 행동으로 양분된 자아(ego)가 자기(Self)의 영역으로 통합되어 한 방향으로 움직이는 것으 로 볼 수 있다(Turner, 2005/2009).

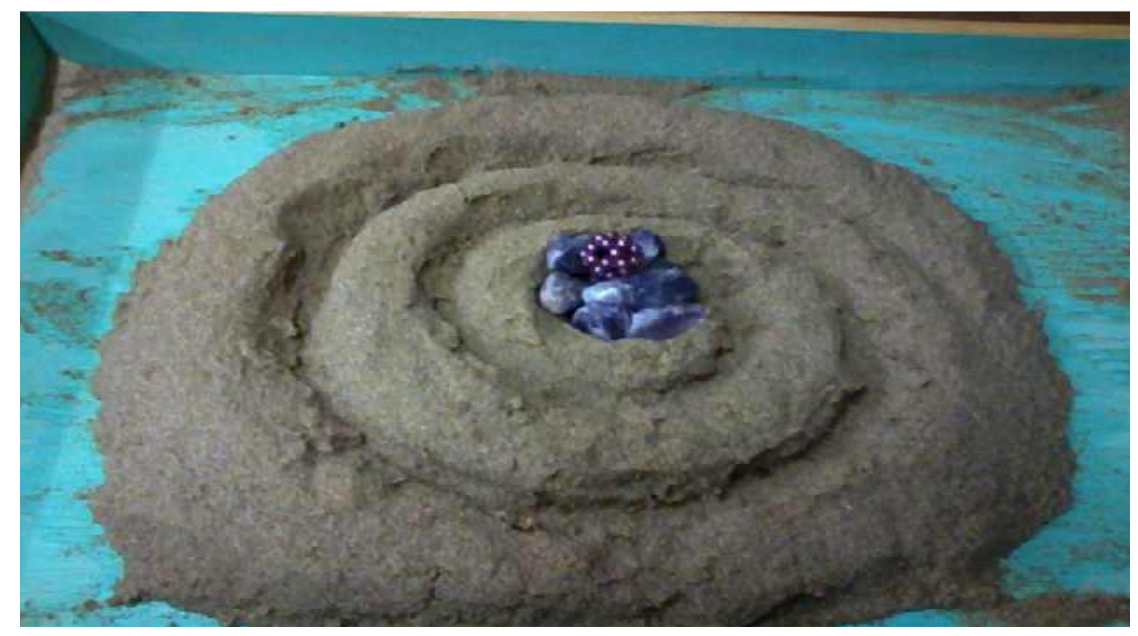

Figure 8. Amethyst Jewel and The emergence of creation and birth Self 
Journal of Symbols \& Sandplay Therapy, Vol.12 No.1.

내담자의 모래상자에 나타난 자수정은 우주적 질료가 하나로 탄생하는 합일의 단계를 상 징하며 내담자는 자신 안에 있는 자아의 개별적 요소들이 통합되어 자기만의 고유성을 표 현한다. 이 단계의 심리적 특징은, 성격 안에 내재하는 대극의 통합과 해결로서 자아와 자 기가 조화로운 관계를 형성하므로 따뜻한 감정이 올라온다. 내담자는 자신의 내면에 있는 깊은 자기의 욕구를 바르게 인식하고 그 욕구의 에너지들을 통해 참 '나'에 대한 통찰을 발 견하고 새로운 '나'로서 일상생활에 적응하게 된다.

내담자는 새롭게 형성된 자기 존재의 힘과 성장된 '나'에 대한 인식을 보석, 진주로서 다 음과 같이 표현하였다.

"제 손이 가는 대로 만들었고 보라색 보석과 진주도 손이 가는대로 가져다 놓았 어요. 물과 모래를 섞어서 모양을 만들어 나갈 때 힘이 느껴졌어요."

이 모래상자의 표현은 내담자가 치유되고 있음을 보여준다. 보석 또는 보석에 버금가는 귀한 바위들은 고유의 색과 빛으로 광채를 떤다. 보석은 수세기 동안 신분을 나타내는 데 이용되기도 했으며, 어떤 보석은 치유와 보호의 힘이 있다고 믿었다. 붉은 보석은 정열과 활력을 의미하고, 일부 보석은 탄생석으로 연결되며 보석마다 각기 다른 함축적인 의미를 담고 있다(Miranda 외, 2008/2010).

연금술에서는 여러 제련의 단계를 거쳐 마침내 연금술사의 내면에 있었던 이미지가 실제 의 물질로 탄생된다. 모래상자에서 합일은 어떤 한 사람의 인생이나 그의 인격 안에 내재 하는 대극의 대결을 해결해냄을 뜻하는 것이며, 한 사람의 자아와 자기(Self) 사이에 조화로 운 관계가 형성되었음을 의미한다. 이것은 내면에서 서로 다른 입장으로 대치되었던 내적 혹은 외적갈등이 통합되고 조화롭게 되었음을 의미한다(신미경, 2013).

보석에 나타나는 생기를 불어넣는 따뜻한 빨강과 정신적 차가움의 색인 파랑의 혼합인 보라는 스펙트럼에 나타나는 두 개의 극단적 대극의 쌍의 결합을 상징한다. 보라에서 나타 나는 따뜻한 빨강과 차가운 파랑의 합일은 전체성과 완전성을 연상하게 한다. 이것은 의식 의 수준에 따라 다양하게 나타나는 대립의 혼합 또는 합일을 가리킨다. 또한, 보라색은 빨 강과 파랑, 즉 스펙트럼의 양극에 있는 것의 합일을 표현하기도 하지만 동시에 같은 대립 물의 건강하지 못한 혼합을 나타낼 수도 있다(Theodor, 2010). 보석과 보석에 버금가는 귀한 바위들은 고유의 색과 빛으로 광채를 띤다. 내담자 모래상자의 보석들은 땅에서 난다는 사 실 때문에 영적인 힘과 순수의 상징으로 신성한 권능을 나타낸다(Miranda 외, 2008/2010).

Jung 은 한 사람의 인생의 의미는 그 사람 안에 있다고 하였다. 이는 인생의 모든 열쇠를 자기 자신 속에 가지고 있음을 의미한다. 다만 그것이 무의식에 있기 때문에 당장 찾을 수 없을 뿐이다. 그것이 인간의 본성이며 태어날 때 가지고 나온 그 사람 고유의 전체 정신인 
자기(Self)이다(이부영, 2004 재인용).

내담자 모래놀이상자의 소용돌이(Spiral)는 에너지와 생명의 리듬을 뜻하는 고대 상징이다. 고대에는 에너지가 소용돌이 형태로 흐른다고 생각했기 때문이다. 소용돌이는 그 형태와 상징성에 있어 나선형과 밀접한 관련이 있으며 자주 혼동되기도 한다. 가장 중요한 것은 이 형태들이 지구의 자전, 회오리바람 등 강력한 힘과 연관된다는 것이다. 대부분의 문화에 서 소용돌이는 여성적 형태로 간주된다(Miranda 외, 2008/2010).

만다라의 상징에 연관되는 상에 소용돌이는 중심으로의 선회를 주제로 한다. 그것은 중 심으로 들어갈 뿐 아니라 다시 나올 수도 있는 길이다. 그런 점에서 상징적으로 미로의 상 징과 함께 자주 언급되었다. 와문(渦文)은 죽음과 재생, 생성과 회기, 후진과 전진, 생명의 원초적 리듬의 영원한 반복의 상징을 나타낸다(이부영, 2004). 내담자의 모래상자에 나타난 나선형 모양과 그 위에 보석 피겨의 의미는 태양과 달, 남성과 여성 에너지 모두를 나 타내므로(David, 1993), 내담자가 본 모래상자 치유작업을 통해서 대극의 합일을 향해 나아 가고 있음을 볼 수 있다.

\section{$\mathrm{IV}$. 결 론}

본 연구는 중년여성의 모래상자에 나타난 바위의 특성 및 상징성을 통해 진정한 자기 (Self)를 찾아가는 개성화 과정을 분석심리학과 연금술적 관점으로 분석해 보았다. 물질의 연 금술적 변환과정에는 석회화, 용해, 응고, 승화, 부패, 분리, 합일 등의 7 가지 작업과정이 진 행된다. 본 연구에서 내담자는 모래상자의 작업과정을 통하여 자기(Self)를 찾아가는 과정을 표현하였는데, 바위와 주변의 상황변화를 통하여 개성화 과정으로서 자기(Self)를 찾아가는 모습을 나타내었다.

모래놀이치료 과정에서 내담자는 모래놀이치료 작업을 통하여 자신의 답답함과 혼돈스러 웠던 감정의 근원을 알게 되었으며, 점차 자신의 내면에 존재하고 있는 깊은 무의식의 그 림자를 발견하고 받아들임으로 통합을 이루었으며, 스스로의 삶의 의미를 새롭게 재조명하 게 되었다.

마지막 모래상자에서 내담자가 보여준 보라색 자수정은 생기를 불어넣는 따뜻한 빨강과 정신적 차가움의 색인 파랑의 혼합인 보라로 스펙트럼에 나타나는 두 개의 대극의 쌍의 결 합을 상징함으로 나타났다. 이러한 보라색 상징은 내담자가 처음에 보여준 분노를 나타 내는 빨강색과 차가움을 나타내는 파랑색의 감정이 모래놀이치료 과정을 통해 통합되었음 을 알 수 있다. 또한 보라에서 나타나는 따뜻한 빨강과 차가운 파랑의 합일은 내담자의 내 면에서 개성화와 자아통합을 위한 새로운 여정을 시작할 수 있는 힘이 생겼음을 보여주었 
Journal of Symbols \& Sandplay Therapy, Vol.12 No.1.

다. 이 결과는 색을 통한 미술심리치료에 관한 연구에서 개인의 심리적 변화 및 내면의 문 제해결이 색과 연결되어 있음을 제시한 김정희(2010)의 연구와 같은 결과를 나타내었다. 즉 모래상자 피규어의 색상변화에 따른 내면의 치유와 자아성장은 연관성이 있음을 알 수 있 다. Harris는 이에 대해 원형과 본능의 관계에 있어서 빛의 스펙트럼에서 적외선 쪽으로 가 까워질수록 본능 즉 생리적 및 본능적 지각에 가깝고 자외선에 가까울수록 원형 즉 심리 적, 영적, 꿈, 이미지 등에 가깝다고 하였다(Harris, 2001).

연금술이 용기에 질료를 넣는 것으로 시작하는 것처럼 모래놀이치료는 모래상자에 손을 넣는 것으로 변환이 시작된다. 내담자의 내면 깊숙이 가라앉아있던 혼란스럽고 수용하기 어려운 내면의 감정이 모래상자의 바위를 통하여 의식의 표면으로 출현하였고, 이렇게 시 각화되고 대상화된 바위를 통해 내담자의 개성화 작업이 진행될 수 있었다. 이러한 개성화 작업은 마치 바위가 연금술의 용기 안에서 새로운 물질이 되기 위해 변환과정을 거쳐야 하 는 것처럼, 내담자는 내면이 자기(Self)가 개성화 과정을 통해 더 성숙하고 통합된 존재로 변 화되는 과정을 받아들이고 견뎌야 함을 인식하였다(Weinrib, 2004).

개성화는 인간이면 누구나 선험적으로 지닌 과제로서 실현되지 못한 자신의 가능성을 각 자의 삶에서 되도록 많이 개발하고 펼치는 것이다. 즉, 진정한 나인 자기(Self)가 무의식으로 부터 전해지는 내면의 소리를 이해하여 자신만의 방식으로 성장을 이루어 가는 것이다. 이 러한 인격의 성숙은 자아의 분화와 강화를 통해 하며 자아(ego)가 자기(Self)와 축을 이루면 서 진정한 자기(Self)의 모습을 찾아가는 과정이다.

개성화의 경험은 정신적 갈등을 통해 대극의 통합을 이루거나 억압된 감정이나 의식을 표현하고 수용할 때 가능하며 상징을 표현하므로 태도의 변화를 가져올 수 있다(이경희, 2005). 또한 개성화는 전 생애를 통해 진행되는 것으로서, 개인마다 고유하고 특별한 자기 체험을 통해 인격이 변화됨을 알 수 있다(Jung, 2004a).

모래놀이치료는 내면의 감정 표출과 이완, 그림자의 만남과 자기인식을 가능하게 하는 심리치료로서, 성인의 개성화 과정을 효과적으로 도울 수 있다. 이는 모래상자라고 하는 외 적으로 표현된 내면의 장소에 자기(Self)의 변화 경험에 따른 감정과 생각을 자유롭게 표현 하는 것이 가능하기 때문이다.

모래상자에서 내담자가 표현하는 자기(Self)의 그림자 문제는 한 방향으로 나타나는 선형 적 표현이 아닌 문제의 발생, 해결, 재발생 등과 같은 나선형의 구조를 가진다. 이런 모래 장면에서 나타나는 내담자의 표현이 소용돌이처럼 나선형적으로 점차 깊어지는 경우에는 같은 주제가 반복되는 것으로 보인다. 하지만 반복될 때마다 내담자는 시련과 고통을 극복 하거나 그 과정을 견디면서 자신의 핵심문제를 점점 더 깊이 직면해 극복하는 통합의 과정 을 거치면서 의식의 영역이 확장된다(장미경, 2017). 이러한 나선형 문제해결의 방향은 결국 문제의 중심을 향하게 되고 내담자는 내면에 존재하는 본질적 문제를 직면하고 해결하여 
개성화 작업을 이루어 낸다.

본 모래놀이치료 과정을 통해서, 내담자는 끌을 대지 않은 자연 그대로의 바위처럼 연마 되지 않은 자신의 내면을 볼 수 있게 되었다. 즉, 내담자는 아들로 태어나지 못한 억울함과 분노 감정을 조절하지 못하여 관계 어려움을 겪는 자신을 보았다.

또한, 내담자는 사랑의 불에 대한 열정과 목마름, 자기를 찾기 위한 고통과 울부짖음, 재 탄생되는 자기, 새로움을 위한 도약, 새로움을 위해 과거를 벗어 버림, 새로운 '나'의 발견, Self인 보석의 출현 즉, 통합된 자기(Self)를 발견한다는 의미에서 연금술 과정을 경험하였다. 바위가 보석이 되기 위해서 끊임없이 다듬어야 되고 순금이 되어지기 위해 연금술 과정을 통과해야 하듯이, 내담자는 자신의 내면 안에 자기(Self)을 발견하기 위해서 고통을 인내하여 야 한다는 것을 인식하였다. 내담자에게 있어서 모래상자의 바위는 삶의 새로운 의미를 깨 닫고 참 자기(Self)를 만나게 함으로써, 자신의 삶이 한쪽으로 치우치지 않고 균형을 찾아가 는 삶의 여정이 되도록 도운 상징이다.

본 연구결과에 따른 정책적 함의는 첫째, 모래놀이치료의 상징으로 자주 등장하는 바위 에 대한 본 연구에서의 개성화 단계 해석을 통해 추후 모래놀이치료 현장에서 치료자가 내 담자의 개성화 단계를 이해하고 해석하는데 적절한 참고자료로 활용할 수 있다. 둘째, 본 연구는 개성화과정에서 중요한 시기를 경험하는 아동, 청소년 및 개성화에 어려움을 겪는 성인을 대상으로, 모래상자 피규어의 변화를 통한 개성화 단계적 성장을 도울 수 있는 자 료로 제공 되어질 수 있다.

\section{참고문헌}

김수정 (2003). 청마 유치환의 심상체계 연구. 연세대학교 대학원 석사학위 논문.

김정희 (2010). 색을 통한 미술 심리치료 연구. 강원대학교 교육대학원 석사학위 논문.

박행자 (2012). 아동의 모래놀이치료과정에서 나타나는 카오스, 죽음, 재탄생. 명지학교 대학

원 박사학위 논문.

안은선 (2014). 모래놀이치료에서 정서의 창조적 분출과 정신적 재탄생의 상징으로서의 화

산의 분석심리학적 의미. 상징과 모래놀이치료, 5(2), 77-87.

이경희 (2005). 중년여성의 자아분화와 자아정체성과의 발달관계 연구. 서울여자대학교 기독

교대학원 석사학위 논문.

이나경 (2016). 촛불: 신성한 보호 공간에서의 의식화의 상징. 상징과 모래놀이치료, 7(2), 81.

이부영 (2004). 자기와 자기실현. 서울: 한길사.

유세연 (2016). 맷돌: 대극의 합일과 새로운 의식창조의 상징. 상징과 모래놀이치료, 7(1), 
Journal of Symbols \& Sandplay Therapy, Vol.12 No.1.

47-64.

유치환 (2002). 생명의 서. 서울: 미래사.

신미경 (2013). 미혼모의 모래놀이치료과정에서 나타나는 연금술적 변환. 명지대학교 대학원 일반대학원 박사학위 논문.

장미경 (2017). 분석심리학적 모래놀이치료. 서울: 학지사.

정은지 (2014). 돌의 집적성에 대한 심상표현. 이화여자대학교 대학원 석사학위 논문.

최민지 (2013). 광물과 암석단원에 대한 초- 중등 과학교과서 내용 분석 - 문제점과 개선방안

에 대하여 -. 고려대학교 교육대학원 석사학위 논문.

한기연 (2007). 설화에 나타난 동굴의 상징성. 고려대학교 대학원 석사학위 논문.

Ackroyd, E. (1993/1997). 꿈 상징 사전. 김병준 역. 서울: 한국심리치료연구소.

Cooper, J. C. (1978/1994). 그림으로 보는 세계 문화 상징 사전. (이윤기 역, 원제: An illustrated encyclopedia of traditional symbols.) 서울: 까치글방.

David Fontana. (1993). 상징의 비밀. 최승자 역. 서울: 문학동네.

Edinger, E. F. (1984/2016). 의식의 창조: 이 시대 융의 신화. (김진숙, 김소영 공역, 원제: The creation of consciousness.) 서울: 돈화문.

Edinger, E. F. (1991). Anatomy of the Psyche. La Salle, IL.: Open Court.

Fideler, D. (2014). Restoring the soul of the world: Our living bond with natures intelligence. Rochester, VT: Inner Tradition.

Hawthorn, N. (1988). 큰 바위 얼굴. 이준연 역. 서울: 웅진출판사.

Harris, J. (2001). Jung and Yoga: The Psyche-Body Connection. Toronto: Inner City Books.

Jung, C. G. (1964/2013). 인간과 상징. (이윤기 역, 원제: Man and His Symbols.) 서울: 열린 책들.

Jung, C. G. (1985b). Traumsymbole des Individuationsprozesses. (Trans. into Korean in 2004).

Jung, C. G.(1985). Erlosungsvorstellungen in der Alchemie. Princeton: Bollingen/Princeton University Press. (Trans. into Korean in 2004).

Jung, C. G. (2004a). 인격과 전이. 한국융연구원 C. G. 융 저작번역서 3권. 서울: 솔 출판사.

Miranda, B. M., Wilkinson, P. (2008/2010). Signs and Symbols. New York: DK. Mircea, Eliade. (1976/2005). Histoire des croyances et des idees religieuses. Paris. Neumann, E. (1974). Die Grosse Mutter. Patmos Verlag GmbH \& Co., KG. (Trans. Korean into 2007).

Robert, A. J. (1989/2006). 신화로 읽는 여성성 "She". (고혜경 역, 원제: Understanding Feminine Psychology) 서울: 동연.

Theodor, Abt. (2010). 융 심리학적 그림해석. 이유경역. 서울: 분석심리학연구소(원판 2008).

Turner, B. A. (2005/2009). 모래놀이치료 핸드북. (김태련 외 공역, 원제: Handbook of sandplay 
안은선 / 바위: 개성화 가정에서 출현한 자기(Self)의 상징 - 모래놀이치료과정에서 나타나는 연금술적 변환-

therapy) 서울: 학지사.

von Frantz, M-L. (1981). Puer aetemus. Munchen: Sigo Press.

Weinrib, E. L. (2004). Images of the Self. The sandplay therapy process. Cloverdale: Temenos Press. (Original work published 1983).

\section{인터넷 검색}

Nativity Scene[웹사이트]. (2021.1.20.).

URL: https://www.google.co.kr/search?q=nativity +scene\&tbm=isch\&tbo.

다이아몬드는 영원하다[웹사이트]. (2021.1.20.).

URL: http://www.naturehistory.org/2016/09/blog-post.html. 